EVALUATION AND ASSESSMENT REPORT ( MAY 30 - JULY 1, 2015)

\title{
FinAL PERFORMANCE EVALUATION AND
} SUSTAINABILITY ASSESSMENT OF THE BUILDING LIVELIHOODS AND TRADE (BLT) ACTIVITY

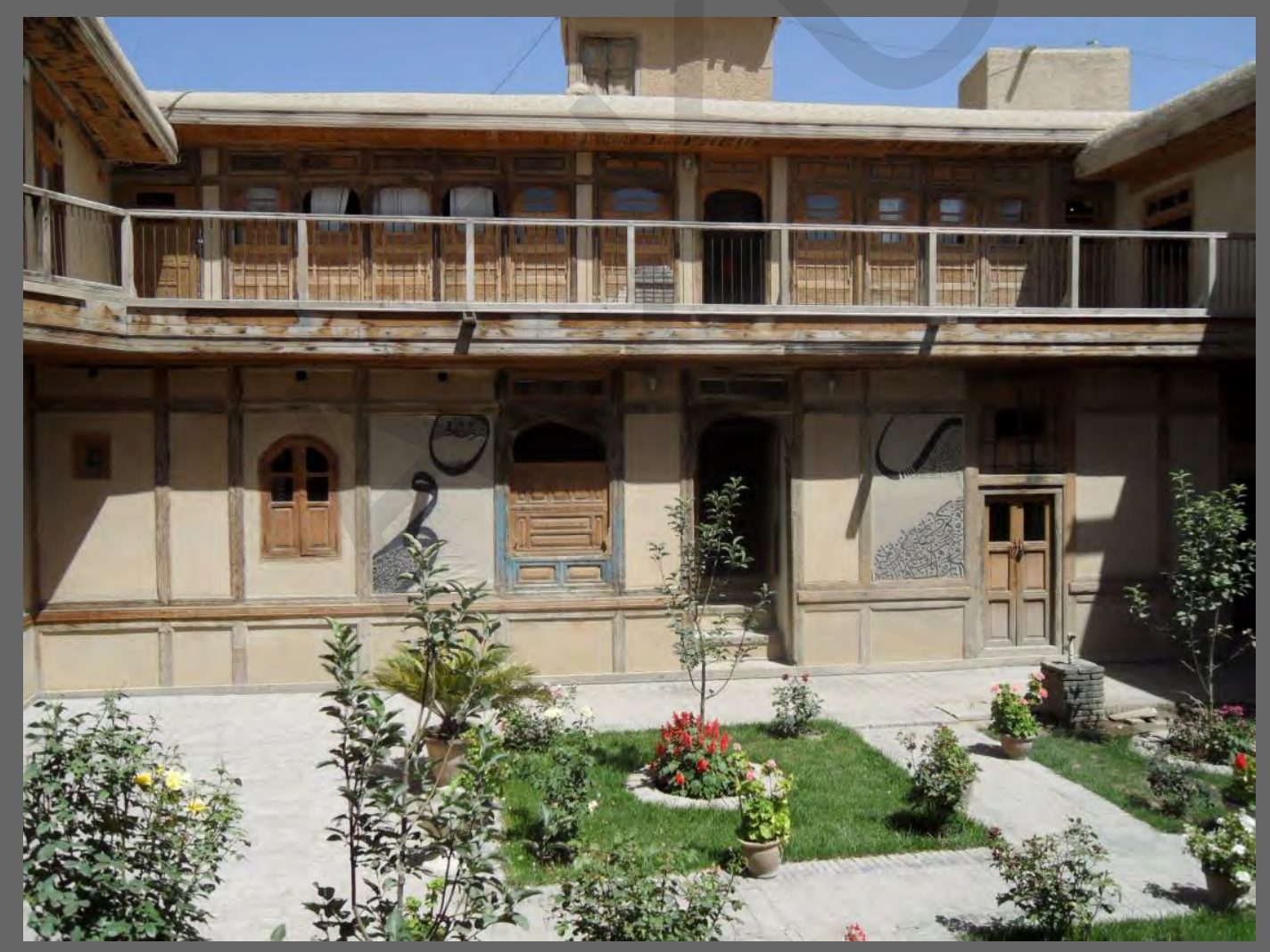

JULY 2015

This report was produced for review by the United States Agency for International Development (USAID). It was prepared under contract with Checchi and Company Consulting, Inc. for USAID's Afghanistan "Services under Program and Project Offices for Results Tracking Phase II” (SUPPORT II) project. 


\section{Activity Signature Page}

This report was contracted under USAID Contract Number: AID-306- C-12-00012. Afghanistan Services Under Program and Project Office for Results Tracking Phase II (SUPPORT II).

This Activity was initiated by the Office of Program and Project Development (OPPD) through Mr. Daryl Martyris, COR/SUPPORT II.

Assignment Title: Final Performance Evaluation and Sustainability Assessment of the Building Livelihoods and Trade (BLT) Activity

Team Leader: $\quad$ Michael Lightfoot

Team Members: $\quad$ Aimee Rose

Manizha Wafeq

Burhanuddin Kamal

Ronald Santos

Activity Start Date: May 30, 2015

Completion Date: July 1, 2015

Michael Lechner, Chief of Party

Waheed Ahmadi, Deputy Chief of Party

Checchi and Company Consulting, Inc.

Kabul, Afghanistan

\section{Disclaimer:}

The views expressed in this report are those of the author and do not necessarily reflect the views of USAID, the Government of the Islamic Republic of Afghanistan, or any other organization or person associated with this project. 


\section{TABLE OF CONTENTS}

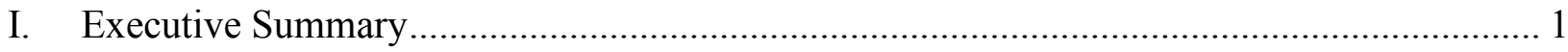

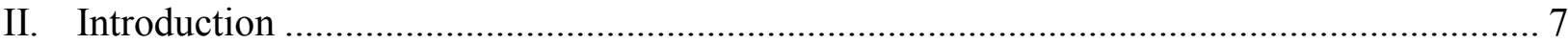

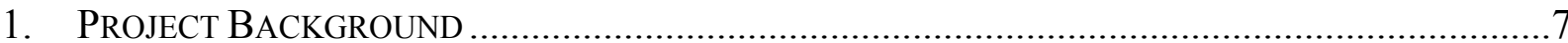

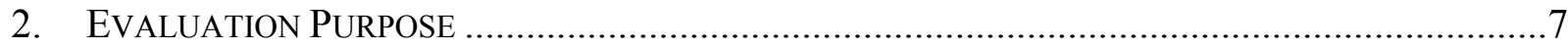

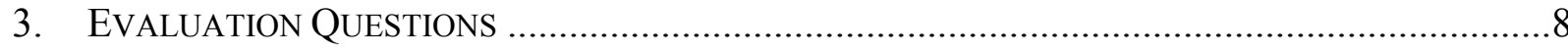

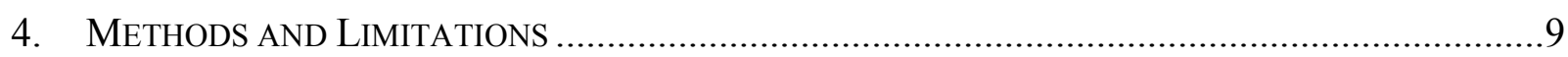

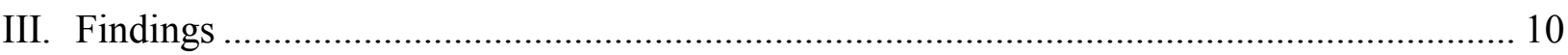

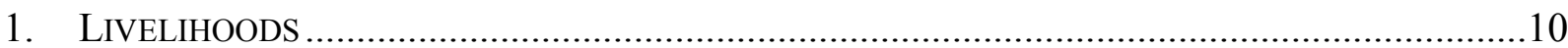

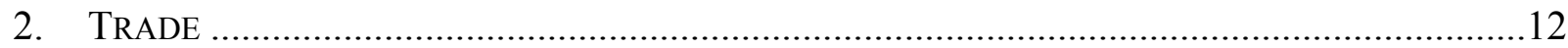

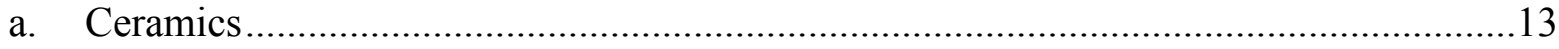

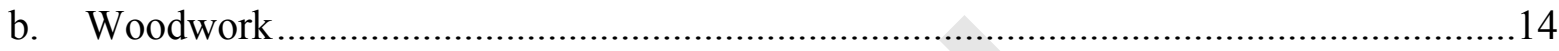

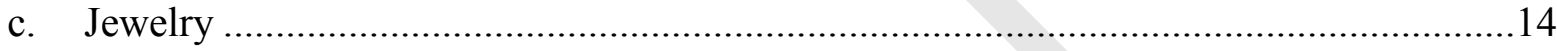

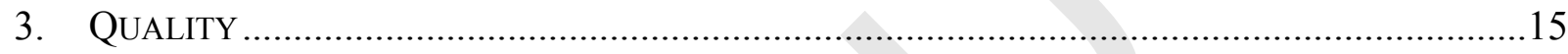

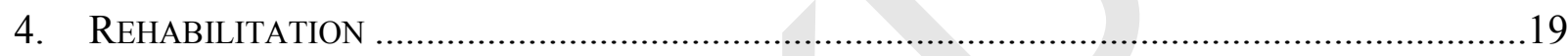

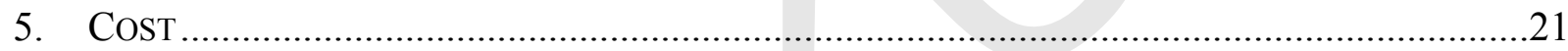

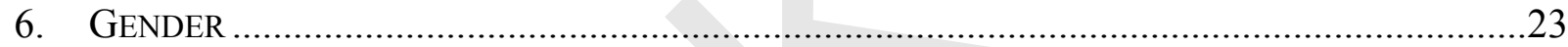

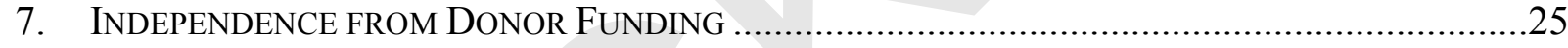

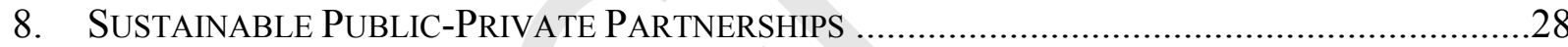

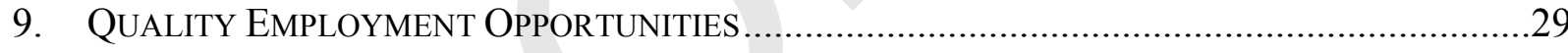

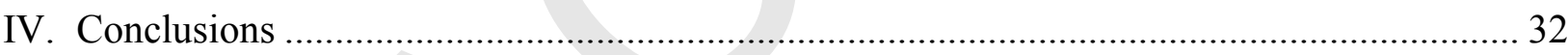

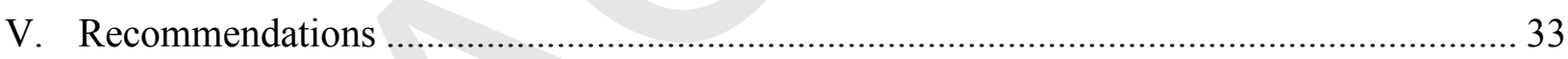

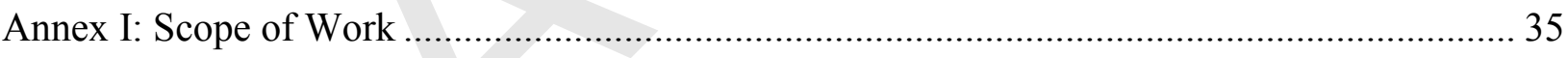

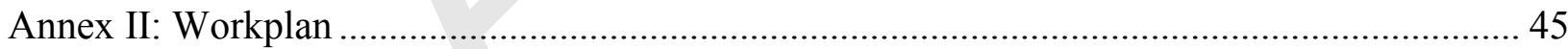

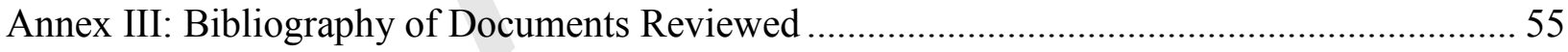

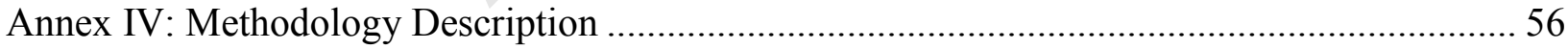

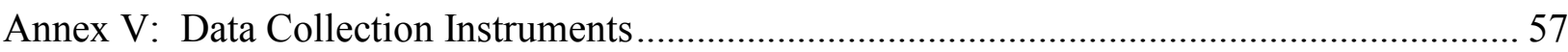

\section{LIST OF FIGURES AND TABLES}

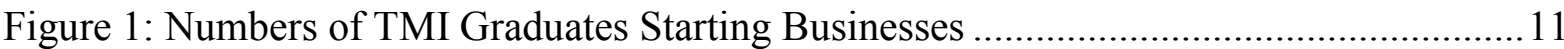

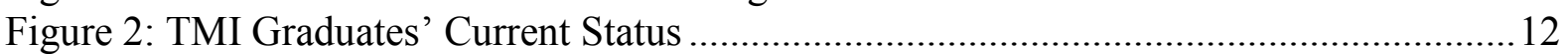

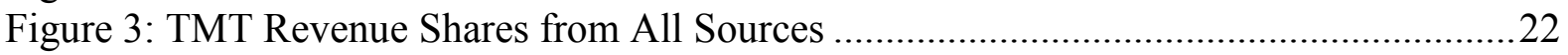

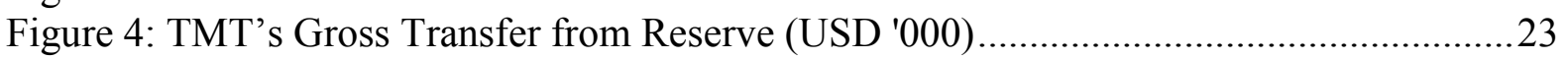

Figure 5: Gender Balance of Current TMI Students in the Different Craft Disciplines..........24

Figure 6: Gender Balance of TMI Graduates in the Different Craft Disciplines.....................25

Table 1: TMI Graduates by Craft Discipline....................................... 13

Table 2: Unit Cost of TMI Graduates with Alternative Assumptions and Cost Models.......27 


\section{ACRONYMS}

ACCI Afghanistan Chamber of Commerce and Industry

AISA Afghanistan Investment and Support Agency

ASDP Afghanistan Skills Development Program

BLT Building Livelihoods and Trade

BOT Board of Trustees

C\&G City and Guilds of London Institute

CIDA Canadian International Development Agency

CPD Continuous Professional Development

EPAA Export Promotion Agency for Afghanistan

FFHC Ferozkoh Family Health Center

GIRoA Government of the Islamic Republic of Afghanistan

ICDL International Computer Driving License

ICT Information and Communication Technology

MOE Ministry of Education

MoIC Ministry of Information and Culture

MK Murad Khane

TFBSO Task Force for Business Sustainability Operations (from US Dept. of Defense)

PPP Public-Private Partnerships

SES Socio-economic Status

SOW Statement of Work

TMI Turquoise Mountain Institute

TMT Turquoise Mountain Trust

TVET Technical and Vocational Education and Training 


\section{EXECUTIVE SUMMARY}

This assignment has been designed to evaluate the achievements of the Turquoise Mountain Trust (TMT) over the seven years that it has benefited from USAID funding; and to assess the sustainability of the operations at TMT into a future that cannot guarantee donor funding in perpetuity. The review team investigated the work of the Turquoise Mountain Institute (TMI), where the craft training takes place; it surveyed the area of Murad Khane, where TMT has undertaken urban renewal projects; and the team met with employers and customers of TMT to evaluate their satisfaction with the skills of the TMI graduates and the quality of the TMT products and artifacts.

\section{ProjeCt BACKground}

Turquoise Mountain Trust, a British-registered non-profit organization, was founded in 2006 with the vision of restoring the historically and architecturally significant community of Murad Khane in central Kabul, and of revitalizing traditional craft skills in Afghanistan. TMT assists the community with accessing health care and primary education, and with promoting Afghan arts and craft. The Trust has established a training establishment, the Turquoise Mountain Institute (TMI) for Afghan Arts and Architecture, to train young people in the areas of woodwork, ceramics, calligraphy and miniature painting, and jewelry and gem-cutting.

USAID has been supporting TMT since 2008, and in 2010 the program was renamed Building Livelihoods and Trade (BLT) with an aim of building economic and trade opportunities for Afghans; providing traditional craft education through TMI; and developing the market for Afghan crafts domestically and abroad through business-development activities. The Total Estimated Cost (TEC) of funding the BLT through TMT since 2008 amounts to $\$ 10,637,111$. Three of the elements - urban regeneration, community development, and business development - were completed in July 2011, leaving only the fourth element - education - for continued support to the end of the program in November 2015.

\section{Evaluation Questions, Design, Methods, And Limitations}

The evaluation questions have been framed to tackle each of the two parts of the investigation separately and distinctly, while recognizing the overlap between what has been achieved at TMT and, on the basis of this, what is planned for the future.

The research design included a mixed-method approach, beginning with a literature review and a critical analysis of documentation provided by TMT and USAID. The data-gathering exercises adopted both quantitative and qualitative methodologies: financial records, including sales figures and projections, were analyzed for consistency and credibility; and surveys of students, graduates, and community members were conducted and analyzed. Individual interviews were held with all of the key stakeholders - students, graduates, employers, business partners, and 
residents of Murad Khane. In addition, focus group discussions were convened with students and graduates. Expert observation was used to assess teaching quality in classrooms and the historical accuracy of the rehabilitation work. The findings were reviewed using critical discourse analysis to discern similarities, patterns, and any inconsistencies. Every possible endeavor was made to reduce the limitations resulting from sampling error and measurement biases. The main limitation was the time available to complete this project, which was a period of less than four weeks from the in-briefing to the final feedback to USAID.

The final evaluation and assessment questions are presented in full on pages 8 and 9. The Evaluation Questions focused on the extent to which TM is contributing the livelihoods of Afghans; how effective the TM program has been in generating trade, at home and abroad for craft products; how much the quality of craft products has improved as a result of TM's intervention; how satisfied the Murad Khane residents are with the rehabilitation of the area; how cost effective the TVET program has been; and how both female and male artisans have benefited from TM's intervention. The Sustainability Assessment Questions focused on the reliability and sustainability of market-based revenue streams; the capacity of TM to build sustainable public-private partnerships to create a strong Afghan "brand" and generate robust sales domestically and internationally; and the extent to which the businesses with whom TM partners are capable of thriving and growing.

\section{FINDINGS}

\section{Livelihoods}

- From TMI almost 20 percent of graduates progress to university or further study - mostly observed among calligraphy graduates. In recognition of their skills and aptitude, the graduates from the calligraphy specialization are, normally, exempted from the first year of study for a Fine Arts degree at Kabul University

- Just over half of the graduates remain in craft trades; many of the graduates work in fledgling businesses that are heavily reliant upon TM for support.

- Through its wider activities in sector, TM has achieved \$3.5 million of craft export sales on behalf of Afghan artisans and businesses, which did not exist before the project commenced its work.

\section{Trade}

- The TM business development department is currently working with 20 businesses many in Murad Khane area.

- Of these 20 businesses, 11 are government-registered, and 12 have been operating for two years or less.

- The brand recognition and reputation of the TM name is successful in generating prestigious large one-off bespoke orders, e.g. a Saudi hotel commission; and repeat bulk orders from ethical traders in North America - e.g., Far and Wide and Bajalia jewelers. 
- Typically, the orders for the international market are sourced by TM from businesses that are able to produce goods of the required quality. Overall TM has supported 15 businesses to export.

\section{Quality}

- TM has demonstrated its capacity to fulfill orders with a consistency and quality that meet the demands of the international market.

- Quality of the product is often achieved at the expense of diversity of supply - only a relatively small number of craft (mostly jewelry) businesses in Afghanistan regularly work with TM to fulfill orders for the international market.

- The quality of the TM graduates is generally mixed - it is reported that, although some have excellent craft skills, many graduates lack job-ready skills, business awareness, English-language skills, and computer literacy.

\section{Rehabilitation}

- TM transformed Murad Khane from a wasteland into an historical treasure.

- The health and education services established by TM are highly valued by the community.

- TM provided electricity supply, water pipes, and sanitation for residents, cleared and leveled the streets, and removed thousands of cubic meters of refuse and accumulated detritus from the area.

- Residents noted that the water infrastructure is no longer functional and they have concerns about the maintenance of their homes and the communal drainage system. While TM accepts responsibility for cleaning the draining system and assisting with particular large repairs, it does not accept responsibility for other work.

- About a quarter of families interviewed complained that TM works for those who have connections with the right people. TM clarified that they are not making promises of assistance; at a minimum, the evaluation team believes that these community responses point to some miscommunication.

\section{Cost}

- The unit cost of TM training is currently very high: more than $\$ 20,000$ per graduate for the three-year program.

- The current cost base at TMI is unsustainable; staffing levels are high; training is inconsistent and not always of high quality, even in the specialist craft areas; three years of full-time study is too long and not suited to the requirements of many craft trades; and the awarding of a stipend to students, while being an excellent pro-poor policy, has not always been justifiable since several young people have been incentivized to study at TMI in the absence of any particular interest, ambition, or aptitude in handicrafts

- An apprenticeship scheme with part-time attendance at TMI would be welcomed by the trades and the companies that the evaluation team consulted. 


\section{Gender}

- As almost all similar endeavors in Afghanistan, the BLT project has benefitted more male artisans and business people than female artisans and business people. The evaluation team focused on the extent to which women participated and benefitted from the project.

- TMI has, for the most part, been careful in its recruitment to maintain a female student population of at least 25 percent, though currently the proportion has fallen to below 20 percent. Women are concentrated in calligraphy, with several in jewelry but few women in the other trades and crafts.

- There are eight female staff out of 57 TMI employees; five are teachers.

- A small number of notably successful female businesses have been founded, e.g., Samira Kitman and her Muftah-e-Hunar Foundation (since 2010); and fledgling jewelry companies that are nurtured under the wing of TM.

\section{Independence from Donor Support}

- Projections show TMI to be self-sustaining, funded by endowment / drawdown funding for at least the next ten years.

- The current high cost base at TMI means that cost reduction measures must be implemented to ensure the viability of these sustainability projections.

- TMI has the potential to be a 'profit' rather than a 'cost' center and thereby be in a stronger position to ensure sustainability after five-to-ten years.

- Growth figures showing income generation from international sales require big capacity expansion from the supply chain.

\section{Sustainable Public-Private Partnerships}

- TM has built successful commercial relationships with several ethical traders in the UK and US, e.g., Kate Spade and Bajalia, and repeat orders are forthcoming.

- Turquoise Mountain has developed a strong brand and reputation. It has collaborated on discrete projects with other companies in the sector, but its relationships with the Afghan government agencies responsible for international trade are less well-developed. Ambitious plans for a sector-wide 'Brand Afghanistan' are in their early stages of formulation.

- The potential for developing PPPs through TM is evident from their past performance; TM has a strong track record in generating and increasing sales for the craft sector, with demonstrable year on year growth.

\section{Viable Independent Businesses and Quality Jobs}

- A small number of enterprises with which TM collaborates are strongly business-savvy.

- TM supports fledgling businesses (currently 20, both male and female), seven of which are, at the moment, in its 'business incubator' operation.

- TM graduates' business-ready skills are, though, somewhat weak.

- The majority of international sales are brokered by TM, but 88 percent of TMI graduates find access to local markets without the intervention of TM 


\section{Conclusions}

The vocational training of the Turquoise Mountain Institute has provided many young people, particularly those from poor socio-economic backgrounds, with some viable craft skills through which to make a living. Moreover, the vision with which the Turquoise Mountain initiative was founded has transformed a formerly derelict area of Kabul into a thriving community.

As the funding for the first phase of its existence draws to a close, the time is ripe for a reappraisal of the objectives and priorities at the Trust. Ambitious plans exist for the establishment of a new wholly-owned private company through which the trading of TMsourced artisanal products can be facilitated. It is proposed that TMI will be funded by a drawdown fund for approximately ten years, as proposed at the outset of the program with USAID. This goal has been met through private fundraising. The evaluation team recommends that the plans for the future be revisited in the light of the findings of this report, including opportunities for generating revenue through the assets of the Institute.

The evaluation team concluded:

- The cost of vocational training at TMI is unsustainably high.

- The current training is not fully meeting the needs of the Afghan craft industries, as many of the graduates are not job- or market-ready.

- The TMT's priorities are currently focused on trading and market development.

- The supply chain to support this market is very fragile.

- The rehabilitation work is valuable and must be protected; a continued focus on community relations is important.

A reevaluation of the priorities for the Trust for the next five-to-ten year period would be to the benefit of all stakeholders so that the impressive achievements over the past decade can be reinforced and amplified over the next phase of development. The following quotation from one of the supporters and international partners encapsulates the love and gratitude of so many people who have worked to help in the realization and sustenance of this truly remarkable Turquoise Mountain project, which has become an institution.

"... It is not whether TM should exist or not - they need to, but how USAID structures the right partnership with them that helps TM focus on their core strengths, namely being on the ground, having the relationships with artisans."

- An international trading partner of Turquoise Mountain, June 2015

\section{RECOMMENDATIONS}

- The Board of Trustees (BOT) should conduct a thorough review of the quality of the programs and activities at the TMI so that they are delivered to the highest standard and in the most cost-effective manner, and so the skills of the graduates are more closely 
aligned to labor market needs. The review needs to assess the viability of TMI as a mixed-economy learning establishment with, for example, full- and part-time craft programs; short course delivery to businesses and the local community; postgraduate research; and international collaboration with vocational colleges, universities, and institutes of higher education.

- The management at TMT and the BOT must ensure that ambitious plans for the commercial developments of the Trust, with the formation of an independent for-profit trading arm, do not become a distraction to the core purpose and principles upon which TMT was founded. In particular, TMI should be kept under constant scrutiny and review to ensure that the courses are suitable to prevailing market conditions, are of high quality, and are aligned to students' and employers' needs.

- On the basis of TM's declared aim to build a strong Afghan brand through international market recognition, the management should work with other NGOs and local Afghan agencies to play a greater role, collectively, in the quality assurance and collaborative marketing of the products of 'Brand Afghanistan.' TM is well-placed, through its reputation and independence, to authenticate and verify many of the indigenous arts and craft products and, in particular, gemstones. The formation of an independent laboratory for gemstone and materials testing and verification is an example of one tangible way in which TM could use its good offices for the greater good of Afghanistan trade.

- TM should re-examine relationships and communication with the Murad Khane community, keeping in mind that the community is not static. Periodic efforts to update the community - both men and women - are important to containing the spread of misinformation and managing expectations. At the same time, it may be worth examining whether favoritism affects relationships with the community and how it can be curtailed. TM might consider additional monitoring methods to ensure that resources are being fairly distributed.

- TM should consider working with the community to draft written responsibilities so that it is clear what the institute will do to assist with the maintenance of structures, garbage collection, drainage, and other essential services, and for what the community and/or shura is responsible. Consulting the Ministry of Culture and Information in the process is also advised, as it currently has responsibility for historical city preservation. 


\section{INTRODUCTION}

\section{Project Background}

Turquoise Mountain Trust (TMT), a British-registered non-profit organization, was founded in 2006 with the vision of restoring the historically and architecturally significant community of Murad Khane in central Kabul. While TMT's mission is to revitalize Afghan arts, it has also provided a lot of assistance to the Murad Khane community, including health care and education services. The Trust has established a training center, the Turquoise Mountain Institute (TMI) for Afghan Arts and Architecture, to train young people in the areas of woodwork, ceramics, calligraphy and miniature painting, and jewelry and gem-cutting.

USAID has supported TMT since 2008, and in 2010 the program was renamed Building Livelihoods and Trade (BLT). Through BLT, USAID's implementing partner TMT, is providing ongoing education and training, expanding economic opportunities, and strengthening livelihoods of students and artisans in the handicraft sector of Afghanistan. The program aims to:

- Build economic and trade opportunities for Afghans through the urban regeneration of the Murad Khane area of Old Kabul City;

- Provide traditional craft education through TMI; and

- Develop the market for Afghan crafts domestically and abroad through businessdevelopment activities.

TMT has been working to realize these BLT aims through:

- Reviving and restoring the threatened artistic heritage of Afghanistan;

- Supporting Technical Vocational Education and Training (TVET); and

- Providing livelihood opportunities for TMI students and graduates in the handicrafts sector.

The total estimated amount of funding the BLT through TMT since 2008 amounts to $\$ 10,637,111$. Three of the elements - urban regeneration, community development, and business development - were completed in July 2011, leaving only the fourth element - education - for continued support to the end of the program in November 2015.

\section{Evaluation Purpose}

The purpose of this assignment is to evaluate the effectiveness of the operations at Turquoise Mountain during the last seven years during which it has been supported by USAID and to assess the viability and sustainability of both of its operational units as Turquoise Mountain Trust and Turquoise Mountain Institute. The evaluation focuses more heavily on the education component compared to the other three BLT elements, which ended in 2011 and are not being considered for 
funding in the immediate future. While not specifically mentioned in the original evaluation SOW, USAID indicated that feedback on the proposed new commercial arm Turquoise Mountain Trading Limited would be welcome. The evaluation team has reported upon the extent to which the USAID resources have been deployed to maximum effect in each of the areas where TMT is operating. The sustainability assessment examines current resource requirements and their utilization and it tests the viability of the future operations, taking into account the outlined business case to create a fully sustainable and profitable public-private partnership.

\section{Evaluation Questions}

This investigation of BLT is comprised of two distinct components: (1) a final evaluation of seven years of USAID-funded programming, and (2) a sustainability assessment of TMI and the Afghan handicraft enterprises with which it works.

\section{Final Evaluation Questions:}

(1) Livelihoods: To what extent has the program activities/initiatives contributed to increasing the economic opportunities for Afghan artisans and businesses?

(2) Trade: How effective has the program been in improving the ability of beneficiaries (students, artisans, and businesses) to market crafts domestically and abroad?

(3) Quality: To what extent has the program increased the quality of products produced by project beneficiaries (students, artisans, and businesses)?

(4) Rehabilitation: How satisfied is the target community with the neighborhood rehabilitation efforts initiated by TMT/TMI and are the results sustainable?

(5) Cost: To what extent was TMI's three-year TVET program a cost-effective means of educating male and female handicraft professionals that are demanded by the Afghan market?

(6) Gender: To what extent has BLT benefitted both male and female artisans and business people?

\section{Sustainability Assessment Questions:}

(7) Independence from Donor Support: As the BLT program comes to an end, to what extent are TMI's operational costs covered by existing or planned future revenue streams from sources other than USAID or other donors? Please examine reliability and stability of any market-based revenue streams.

(8) Sustainable Public-Private Partnerships: Can the current structure of TM-including TMT, TMI, and all partner organizations - be mobilized to create a fully sustainable and 
profitable public-private partnership and business venture that is capable of meeting the objectives of (a) creating a strong Afghan 'brand', (b) establishing wide market presence, and (c) generating robust domestic and overseas sales?

(9) Viable Independent Business and Quality Jobs: To what extent are the Afghan handicraft enterprises with which TMT and TMI collaborate sustainable, independent, and businesssavvy organizations that are capable of providing quality jobs to male and female graduates of TMI and ensuring adequate revenue streams?

\section{Methods And Limitations}

The research design used a mixed method approach, beginning with a literature review and a critical analysis of documentation provided by TMT and USAID. The evaluation team used both quantitative and qualitative methodologies to collect data: financial records, including sales figures and projections, were analyzed for consistency and credibility; and surveys of students, graduates, and residents were conducted and analyzed. Individual interviews were held with all of the key stakeholders - students, graduates, employers, business partners, and households in Murad Khane. Focus group discussions were also convened with students and graduates. Expert observation was used to assess teaching quality in classrooms and the historical accuracy of the rehabilitation work. The findings were reviewed using critical discourse analysis to discern similarities, patterns, and any inconsistencies. The evaluation team met regularly to discuss and review the evidence, and to ensure a commonality of approach and a shared understanding of the emerging issues.

Because the staff, student, and graduate populations were small, there were a limited number of related businesses, and the community itself included less than 100 households, the research team was able to interact with a sizeable proportion of the population of interest. The main methodological concern was that the team speaks with a representative group, which was addressed by systematic sampling wherever possible. In addition, as with any human subject situation, subjects are often reluctant to give socially unacceptable or disloyal answers. The research team endeavored to overcome this limitation through employing locally-based Darispeaking data collectors to gain the trust of the subjects. The research results were also triangulated with TM's own research findings, and the data was re-examined where any discrepancies arose. Sampling bias was mitigated by meeting with at least one household in each compound in Murad Khane; through interviewing by telephone all of the available TMI graduates; conducting a survey with all the current students; and by holding focus groups with representative groups, both male and female, of former students. In total, the team conducted 272 interviews, of which 40 were with male or female heads of households in Murad Khane. 


\section{FINDINGS}

\section{LiVELIHOODS}

The Turquoise Mountain Trust's Business Development Team reports that it currently actively works with and/or supports 20 local businesses. ${ }^{1}$ Of these 20 businesses, nine are not registered with the Afghanistan Investment and Support Agency (AISA), and 12 businesses have been in existence for two years or less.

In practice, there are only 11 companies with which Turquoise Mountain is regularly liaising and sourcing products for resale. Three of these companies had a commercial existence prior to TM's foundation, and the remainder can be said to owe their existence to the work of TM. To this extent, TM can be said to have contributed to the increasing economic opportunities of Afghan artisans, but its impact has been small; and the number of direct beneficiaries, in terms of craft trades and businesses, are probably fewer than 150 people.

The evaluation team looked at the other beneficiaries of TM's work, such as households of the Murad Khane area, graduates of TMI who have progressed to further education and training, and the wider crafts businesses in general within Kabul.

Analysis of the survey of the Murad Khane families indicated that 85 percent of them reported no change in their income or prospects of finding jobs. Ninety percent reported no change in their ability to purchase food and essential items, while ten percent reported an improvement. Other than a few individuals who were directly employed by TM, the evaluation team found no change in employment patterns that would indicate a general improvement in livelihoods for local residents.

It is a great challenge for young graduates to contemplate starting their own businesses after they have completed three years of full-time training at TMI. Nonetheless, of the 187 students who have graduated since 2011, 25 have taken this bold step - the distribution across the different vocational specialties is indicated in Figure 1 below.

Calligraphy and ceramics are the most challenging sectors in which to start trading, and jewelry has proved to be the most popular, followed by carpentry. In both of these latter trades, carpentry in particular, TM has assisted the businesses in their early years of operation with loans or the use of expensive specialist equipment. Apart from those students who have started their own businesses, just under 25 percent, have found employment in the craft trades, but around half of

\footnotetext{
${ }^{1}$ Data from TM Business Development Unit
} 
these are not working in the crafts in which they have been trained. Almost 20 percent go on to further training or higher education, just over ten percent are unemployed, and the remainders are working in other sectors of the economy.

\section{Figure 1: Numbers of TMI Graduates Starting Businesses}

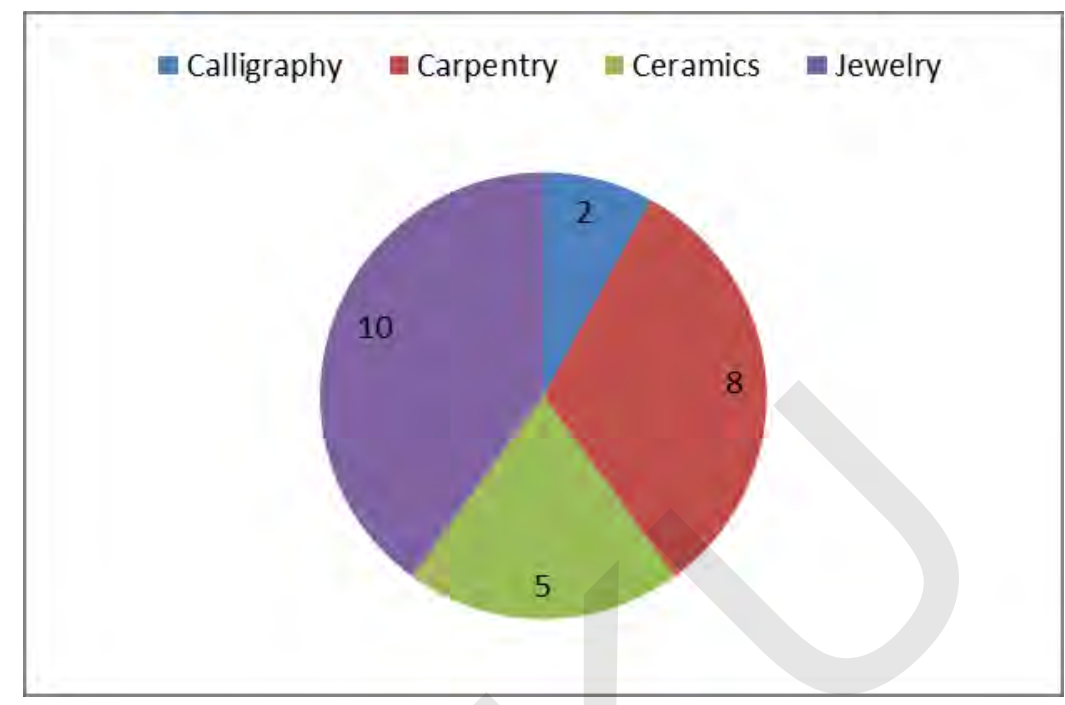

Most employers who were consulted by the evaluation team, stated that TM graduates' skills were not sufficiently well-developed by the end of their time at TMI. Many students had acquired skills and knowledge, often in a wide area of the trade, but their skills and speed of operating were underdeveloped for the commercial environment. Several businesses indicated they would welcome the opportunity for TMI students to work part-time as apprentices while spending the rest of their time at the Institute. In this way, the students would have the benefit of understanding the pressures, the pace, and the demands of working in a commercial environment while developing their knowledge and understanding of a wider range of materials and techniques.

A move to a more work-related approach to training would represent a departure for TMI. It would, necessarily, be reflected in the student recruitment process, and students from the outset would have an opportunity to gain a taste of life in the industry by spending at least half of their time in busy workshops. This would be to the benefit of both students and employers since, at present, the observation of several employers has been that they were surprised at how little interest several of the TMI students they have worked with have shown in the respective trades. Only a minority of the students were said to be enthusiastic and reliable. The suspicion arises, therefore, that students may have been perversely incentivized to attend craft training at TMI at least in part to qualify for the $\$ 50$ per-month stipend. This suspicion was confirmed by the verbal contributions made at the graduate focus group. The graduates who were consulted did indeed report that the stipend had, for some, been a strong factor in their choosing to remain at the Institute. 
The pro-poor recruitment policy is evident in the analysis of the socio-economic status (SES) of the student and graduate population. An apprenticeship model for training delivery would mitigate any negative consequences of removing the stipend, since all of the employers who were consulted agreed that they would be prepared to pay the TMI apprentices a small wage while they were engaged in work experience. The Foundation should be in a position to maintain its pro-poor philosophy by providing a scholarship for those potential student apprentices who were truly needy.

It should be noted that there is a distinct pattern in SES across the different disciplines. Most students in calligraphy come from higher SES families, and most students in the more physical craft trades come from lower SES households.

\section{Trade}

The team interviewed 108 out of 187 TMI graduate students. Twenty of the graduates have started higher education programs, and 25 of them have started businesses in their fields. Twenty-eight of the students have started working with another company in the same field, and five of them have become instructors. On the other hand, 12 of the graduates do not work in the fields in which they have received training; they work as a translator, guard, and shopkeeper, and in offices. Eighteen of the graduates are jobless.

\section{Figure 2: TMI Graduates' Current Status}

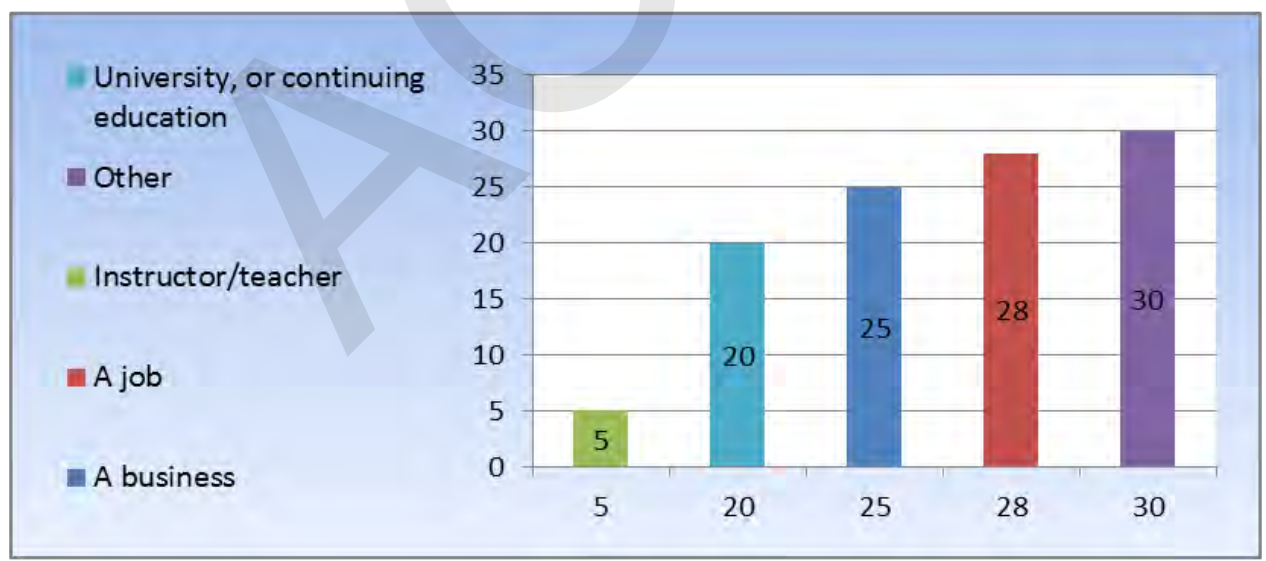

The numbers of graduates from 2009 until 2105, by specialty, are presented below. 
Table 1: TMI Graduates by Craft Discipline

\begin{tabular}{|l|c|c|c|c|c|c|c|}
\hline $\begin{array}{c}\text { Year of } \\
\text { Graduation }\end{array}$ & 2014/15 & $\mathbf{2 0 1 3 / 1 4}$ & $\mathbf{2 0 1 2 / 1 3}$ & $\mathbf{2 0 1 1 / 1 2}$ & $\mathbf{2 0 1 0}$ & $\mathbf{2 0 0 9}$ & $\begin{array}{c}\text { Total per } \\
\text { Field }\end{array}$ \\
\hline Calligraphy & 12 & 7 & 5 & 7 & 7 & 17 & 55 \\
\hline Jewelry & 13 & 10 & 3 & 8 & 13 & & 47 \\
\hline Woodwork & 13 & 7 & 7 & 8 & 11 & 7 & 53 \\
\hline Ceramics & 5 & 6 & 7 & 3 & 5 & 6 & 32 \\
\hline Total & 43 & $\mathbf{3 0}$ & $\mathbf{2 2}$ & $\mathbf{2 6}$ & $\mathbf{3 6}$ & $\mathbf{3 0}$ & $\mathbf{1 8 7}$ \\
\hline
\end{tabular}

The majority of the graduates (49 percent) do business solely in Afghanistan, and around 39 percent of them are doing business both in Afghanistan and abroad. Twelve percent of the graduates are only doing business abroad, according to the phone survey.

Many of the TMI students and graduates aspire to have a business of their own; and through this, to develop their capacity to deal with domestic and international customers. Another group of students, those who do not have enough capital or capacity to run a company, wish to work at a good company and earn a competitive salary. TMI has supported, for a year or more after their graduation, those new graduates who aspire to business ownership by providing them with workplaces, startup machinery, tools, and some office equipment, together with regular advice and support.

The evaluation team conducted interviews with six new business startups that have either benefited from TM support or have started their own business with capital from their families or personal savings. Since each of the artisanal trades has its own particular flavor, the strengths and challenges the various startup companies in each of the specialties of ceramics, woodwork, and jewelry are discussed separately here.

\section{a. Ceramics}

Afghan Traditional Pottery and Feroz Bokhdi Ceramics (FBC) and Tiles are companies located within the TMI compound and have been running for five years. Both companies have employees from outside TM and, currently, 20 students each from TMI who are being trained in ceramics. The companies are happy with the support they received from TMI for their product marketing abroad and for direct selling through the TMI shop.

However, the owner of FBC, who is also a ceramics teacher at TMI, stated that graduates from TMI need six months to five years of work experience to be a fully-qualified employee or ceramic worker at an acceptable level for the international market. He also suggested that it would be beneficial to have more practical work with students rather than theory. He thinks the 
extra subjects such as Dari, Pashto, and others should be removed from the curriculum; instead, it would be to students' great advantage to have more English-language and management subjects. These subjects should be taught in a practical way; students additionally should learn about project management and marketing.

The graduates who participated in the focus group discussions were unanimous in the opinion that they did not receive the necessary skills, knowledge, and understanding needed to start a business. Skills such as writing a business plan or a marketing strategy or understanding cashflow management were said to be sorely lacking.

The companies agreed, in principle, to the idea of having a TMI student apprentice for a period of time. While this agreement was conditional upon logistical support from TMI - for example, tutorial oversight of the students and assistance with daily transportation, company managers declared themselves ready to pay a modest wage and daily expenses to the apprentice.

\section{b. Woodwork}

The quality of the woodwork produced by TMI is good, but would be better if the students had more exposure to the commercial realities of a busy workshop. According to the broker who assures the quality of products coming from various workshops to be resold under the TM brand, there are only a few woodworkers who can provide good-quality product; the remaining woodworkers do not produce pieces of sufficient quality for resale.

The evaluation team visited a woodworking company run by TMI graduates. They were grateful for the machinery from TMI but complained the machines are very old models and are not suitable for the modern market. This company had received only one order from TMI, and other orders are sparse. The owner believes he might not be able to sustain his business after this year if he is asked to leave the business incubator space provided by TMI. Driven by commercial imperatives, the TM trading arm has had to source much of the products to fulfill its order from established TM woodworking partner companies, rather than from new start-up businesses.

\section{c. Jewelry}

The team visited five jewelry designers and manufacturers, two female- and three male-owned companies. The female owner of one company had previously worked for more than three years with Jawid Noori Jewelry, a jewelry manufacturer that has been operating for more than 12 years. She concluded that in order to have her own business and overcome difficulties of gender segregation in the workplace, she would need to hire only female employees. To realize her ambition, she took workshop space in the TM compound, a professional environment where she could take orders for jewelry. Additionally, she was able to hire TMI jewelry graduates. The proprietor has high hopes and a strong desire to run her own business, but is prepared to run the business with one or two more partners, if market forces demand it. 
Another female-owned company is also currently operating out of a workshop space in the TM compound. The owner of the company started her business in partnership with another woman who had also worked for several years with Jawid Noori. They have received only small orders from TMI and rarely have individual orders from outside or from TMI visitors. They were happy that TMI provided them the place to work rent-free; otherwise they would have not been able to run the company.

Three other new businesses, established by recent male graduates, have received some machinery and tools from TMI. The owners, nonetheless, said they are not happy about their situation. They claimed that TMI had offered support and routes to market for their products; but, in reality, although the companies had received sample orders from TMI, few of these had translated into full bulk orders. They were told that their test productions had resulted in samples that were judged to be of low quality for TM's international partners. The company owners said they were disappointed at not receiving sufficient feedback from TM to help them improve their quality shortcomings for future orders. They complained that all the orders are going to a small number of companies that, they purport, receive special favor.

The interviews with company owners indicate the tension between nurturing new talent and upand-coming businesses and the harsh commercial realities of selling in international markets. These are among the first hard lessons that any new company learns. Additionally, all of the TMI graduates to whom the team spoke mentioned their poor preparation from a business perspective. The business studies program at TMI is too theoretical and academic, it does not even prepare students with an understanding of the business basics, such as stock control and sales and marketing. It must be reformed to be able to prepare graduates for the hurdles they will face as entrepreneurs.

The evaluation team was encouraged to learn about a new training program for budding entrepreneurial artisans, called the Artisans Toolkit. The program is the product of collaboration between several NGOs and provides a well-structured and a highly relevant approach to business studies, which has been well-contextualized for Afghanistan. TMI is well-placed to play a role in the dissemination of these excellent training materials.

\section{QUALITY}

As the volume of the manufactured products and their sales has increased in line with the growth of TM's operation, the need for sub-contracting has developed. Whereas, originally, the products for sale in TM retail outlets were manufactured by students and direct associates in the TM workshops, increasingly these products are made by sub-contractors in the jewelry and carpentry workshops of TM's partner companies. More frequently, TM is operating as a sales agent or 
broker. As such, it has had to develop rigorous quality assurance processes to ensure that anything sold under the TM brand is of the highest quality.

The international marketplace demands quality and consistency from its suppliers and manufacturers. As demand has grown from one-off individually-crafted and bespoke jewelry items to, increasingly, bulk orders for multiples of identical pieces, the need for skilled and discriminating quality assurance intermediaries has arisen. TM has met this challenge well, and its capacity to assure excellent quality is evident from the multiple and repeat orders from international jewelers and fashion brands.

One such brand is Bajalia, a prestigious US-based ethical fashion retailer. The company placed an order to produce 550 handmade pieces of jewelry for the North American market. Bajalia previously sourced jewelry from producers in northern Afghanistan, but found issues surrounding quality, delayed production delivery, and communication difficulties insurmountable. The retailer contacted Turquoise Mountain, which, in turn, gave seven small graduate businesses the opportunity to make samples for the order. TM negotiated a price and production time that was able to meet the needs of both the artisans and the retailer, and the Trust then financed the small businesses to produce the first set of samples. Targeted training courses were provided to the businesses by TM's international jewelry consultant, based on the specific requirements of the pieces, such as antiquing and gold-plating, and the client was completely satisfied. Following the success of this first order, Bajalia went on to place a new order for over 400 additional pieces.

A tension exists, nonetheless, between 'quality' and 'diversity of sourcing.' When fulfilling large international orders, TM relies on a small number of established and trusted sources to meet the demand. A number of the small start-up fledging businesses that have been set up under the aegis of TM reported their frustration to the evaluation team, that though they had been invited to provide test samples to meet the needs of an international client, frequently their test orders had been rejected on quality and consistency grounds. If TM is to continue to nurture these small businesses, then it must find a way of reconciling the quality/diversity conundrum.

In woodworking and carpentry, the high quality of Turquoise Mountain's associates is evident. Many of them are experts in the art of mashrabiyya - the skill of making joints without using metal or glue. The artisans use complex wooden joints to join hundreds of slender pieces of wood. Among the many skills the students are taught include a style of traditional carving that comes from the remote mountain province of Nuristan. The international reputation and the quality of TM products have enabled the Trust to secure a number of high-value commissions. For example, in 2009 Turquoise Mountain associates renovated the library in the Embassy of Afghanistan in Tokyo. This included refurbishing an elaborate pair of solid walnut entrance doors in four-layer carving, based on ancient doors from Central Asia. In 2015, Turquoise 
Mountain's woodworkers were asked to provide bespoke Jali screens for a New York City townhouse. Working closely with a firm of architects, the TM craftspeople produced designs for the interior that were tailor-made to fit harmoniously with the surroundings.

Securing high-value, high-volume commissions has recently become an important part of the sales and marketing operation at TM. A major five-star hotel in Saudi Arabia commissioned TM, in 2014, to produce hundreds of hand-painted pieces of calligraphy and miniature paintings for the hotel's lobbies and suites. In 2013, the students produced a great many artifacts to display at the Museum of Islamic Art in Doha, and preparations are currently underway to mount a major exhibition of Islamic Art and Architecture at the Smithsonian Museum in Washington DC.

There is, though, a tension between the production of high-quality items for display in these major international exhibition centers, and the pursuit of a broad and diverse curriculum that exposes students to a wide range of styles and techniques. Many of the former students with whom the evaluation team spoke were critical of the time they spent producing carvings and panels for the exhibition in Doha, to the detriment, they said, of broader studies and skills development.

In contrast to the high quality of the materials for sale that the TM-associated companies are producing is the poor quality of the curriculum and the inconsistency of the teaching at TMI. The evaluation team interviewed several graduates and current students, and, additionally, spoke with employers and independent organizations with which TMI has had dealings. The table below summarizes how the teaching methodology has been implemented in TMI. The details were analyzed by phone and by direct surveys with 231 graduates and current students.

\begin{tabular}{|l|c|}
\hline \multicolumn{2}{|c|}{ The Predominant Style of Teaching } \\
\hline $\begin{array}{c}\text { Teaching } \\
\text { Methodology }\end{array}$ & $\begin{array}{c}\text { Number of } \\
\text { respondents }\end{array}$ \\
\hline Interactive & 36 \\
\hline Lecture Style & 4 \\
\hline Practical & 126 \\
\hline $\begin{array}{l}\text { Lecture style and } \\
\text { Practical }\end{array}$ & 66 \\
\hline Total & 231 \\
\hline
\end{tabular}

Additionally, the evaluation team spent three days touring classrooms and workshops and directly observing the teaching sessions. It was clear that the relationships between the teachers and the students are mainly calm and mature, and based upon mutual respect. However, the sessions observed lacked rigor and challenge, and the objective criteria for the assessment of students' work were not clearly apparent.

Although the City and Guilds $(\mathrm{C} \& \mathrm{G})$ certification places some externally-verified standard on the quality of the artifacts that the students create, the External Verifier does not visit Kabul and relies on photographs of the students' artifacts sent to the regional C\&G office in Dubai. Certainly, the quality of the artifacts photographed is high, and the C\&G process is carried out in terms of documentation and procedures, but the assessment does not take into account the process the students have gone through to produce the artifacts. The C\&G Certificate, as 
designed, is not time-bound; the assessment is carried out on the basis of 'learning outcomes.' The fact remains that the Certificate can be achieved in less than a year of part-time study at colleges in the UK. In comparison, spending three years on a full-time program at the TMI appears to be excessive.

Perhaps when TMI was established in 2006, the level of vocational and craft skills training in Afghanistan started at such a low level that three years of study was necessary to create a calm and sheltered place for skill development at the TMI. In the intervening seven years, there have been huge investments in the Technical Vocational Education and Training (TVET) sector in Afghanistan through, for example, USAID and the World Bank projects such as the Afghanistan Skills and Workforce Development programs. In vocational teacher training too, there have been developments, such as the new GIZ-funded Technical Teacher Training Academy in Kabul. In the light of these developments, the quality and opportunities available for both students and teachers of TVET, the quality of teaching, and the curriculum content at TMI is in need of review and re-evaluation - this includes both craft skill teaching and learning, as well as the noncraft curriculum subjects. On the grounds of both cost and quality, the three-year full-time programs for vocational skills are unsustainable.

Any curriculum review that the TMI undertakes should also urgently take account of the supplementary curriculum. Currently, the graduates' skills in IT, business awareness, and English language are all very weak. The employers who were consulted welcomed the opportunity to have, as part of their workforce of the future, new employees with strong skills in these areas. English-language and computer skills are not only valuable for sales and marketing, but also for industrial production too. Many of the machines have instructions in English, and many of the designs that are now being produced require a degree of computer literacy to enable the realization of handwritten sketches and notes into instructions for industry-scale production. Also, for further studies and research, students need to know English to learn and keep up-todate on international standards and market demands.

The tension between scale and quality will always exist as a craft industry aims for at-scale production in order to fulfill large orders from overseas buyers. The development of the breadth of skills to address these market imperatives should not occur at the expense of the rare craft skills, the preservation of which was one of the principles upon which TMI was founded. On the contrary, it is through the possession of these broad market-ready skills that TM graduates may stand out as being of a higher caliber than those from the more general vocational schools. TM graduates could, and should, have a skill-set that embraces both the needs of the modern mass marketplace and an awareness of and skills in the ancient traditional arts and crafts. 


\section{REHABILITATION}

The Turquoise Mountain rehabilitation efforts began as early as 2006 and were generously funded by USAID and the Canadian International Development Agency (CIDA), as well as other donors. The restoration works have been well-documented in narrative and photographic form and represent a significant achievement in restoring one of Kabul's most historical areas.

While there is agreement that the overall effort of Turquoise Mountain in Murad Khane was significant and has made a positive impact on the community, families in the area differed in terms of their satisfaction with the restoration work done on their own compounds. While 47 percent described the work quality as good or very good, 28 percent described it as average, and 25 percent as poor. The responsibility for maintenance and small repairs of the structures now rests with the community, according to the head TM engineer. However, almost 60 percent of all respondents say they are not able to do repairs without assistance, with almost all of them citing cost as the primary limiting factor.

In involving as many men as possible from the Murad Khane district in the restoration work as paid laborers, Turquoise Mountain intended to transfer marketable skills and believed the experience would help the temporary laborers secure better employment in the future. In the survey of 40 of 86 households, the evaluation team did not find evidence of this expected impact. One woman reported, and several others agreed, "This was just ordinary work and my husband didn't get any new jobs because of it." No respondent was able to cite future employment as a benefit of having participated in the rehabilitation as a laborer. The experience may have helped some, but it did not have the significant effect that was expected.

The restored buildings require annual roof maintenance to prevent damage from water ingress. Turquoise Mountain's head engineer explained that while this is the community's responsibility, TM delivers necessary materials every year before winter. The evaluation team was unable to corroborate this statement. In follow-up visits to eight families, none knew about such materials being available. Many said they do the maintenance themselves when needed, but two individuals from the eight families said they have applied plastic to the roof to avoid having to do so. A quarter of the families surveyed rent rather than own their homes, another factor related to the lack of motivation for maintenance. The population is also somewhat transient. According to the evaluation team survey, 17 percent of families moved to Murad Khane after the restoration work began.

TM provides some assistance for certain repairs, largely coordinated through the engineering department and three paid Community Liaison workers, but many community members complained that access to assistance was based on "knowing someone." When asked about the fairness of the way restoration work was conducted, 44 percent of respondents said they thought it was not carried out fairly. One woman's comment was representative of many responses, "If you don't have connections to someone at Turquoise Mountain, they won't work for you." Ten 
of the 40 household members interviewed mentioned needing connections when asked why they thought the process was fair or unfair.

Alongside the structural rehabilitation, TM originally intended to provide full infrastructure services to the Murad Khane community, including water, drainage, and electricity infrastructure, along with rebuilding all side streets. While the community reported being quite satisfied with the quality of the electricity infrastructure (services are now provided by the municipality) and side streets, 77 percent of respondents said the quality of water services is poor. TM did build the infrastructure to provide water, but after handing over responsibility of water service delivery to the government, residents failed to register and pay water fees, which led to the cessation of services. Half of the community members surveyed said the quality of the drainage system is poor. Qualitative responses indicate that the community is displeased with the maintenance of the drainage system, for which TM takes responsibility, rather than the infrastructure itself. Respondents requested more frequent cleaning of drainage in places where garbage collects. ${ }^{2}$

The evaluation team found that relations between TM and the community are not uniformly positive, even though all families consulted admitted that the organization has done a lot for Murad Khane. TM's Country Director described the organization's consultation strategy as meeting face-to-face with individual households. However, almost a quarter of respondents were not satisfied with TM's consultation process with the male head of their household. Seventy percent of respondents said that TM has not consulted with female heads of their household. While only 18 percent were dissatisfied with the way in which women are involved in consultation process (not an expectation in Afghan culture), three women voiced their opinion that both men and women should be consulted more often. Complaints from the community largely stemmed from perceived favoritism in the distribution of resources. Interviewers also noted that some community members believe TM to have responsibilities they do not claim, such as for all general repairs and ongoing water supply services.

To complement the rehabilitation of the dwelling spaces, Turquoise Mountain Trust also introduced health and education interventions in Murad Khane. The Trust established a clinic and a primary school that offer supplementary education to neighborhood children, training to women in literacy and tailoring, and provide community health and hygiene education. TM constructed the Ferozkoh Family Health Center (FFHC), which continues to provide primary health, maternal care, and laboratory services to Murad Khane and the wider community. TM solicited donor resources to stock and fund it through the early years and negotiated a

\footnotetext{
${ }^{2}$ Also mentioned in the transcription of TM's 2013 Socio-Economic Survey Focus Group Discussions.
} 
Memorandum of Understanding with the Ministry of Public Health, even though FFHC is not part of the government system. TM decided to hand over daily management of the clinic to an NGO specializing in healthcare. FFHC has developed a plan to increase revenue over time by raising fees gradually while granting fee reduction to needy patients. Currently, approximately half of the running costs are recovered through fees, and the sustainability plan indicates that fees will continue to rise to meet more of the costs.

Murad Khane residents made no allegation of favoritism at FFHC, even though fee reduction decisions are made on a case-by-case basis by the clinic director. Residents who participated in the survey overwhelmingly praised the clinic and staff, and 83 percent agree that the current fee structure is affordable. Clinic records show an average of about 950 visits from Murad Khane patients per year, or between one and two visits per person per year. Survey results show that 93 percent of households use the clinic, and qualitative data corroborated the number, as many residents go frequently. Approximately 15 percent of all patient visits to FFHC are made by Murad Khane residents.

\section{Cost}

The unit cost of educating and training TMI students over the course of three years of full-time study is extremely high. USAID and other donors, most notably CIDA, have contributed generously during seven years of support to TMI, and a total of just 187 students have graduated, with only around half of them remaining in the craft trades to earn a living.

\section{Overview}

The cost-effectiveness of TMI/TMT is linked with its sustainability plan. Planning for sustainability has taken place since 2008. At that time, according to TMT financial statements, institutional donors such as USAID and CIDA required a sustainability plan in order to justify their funding of TMI core activities through 2015. These core activities included community regeneration and development, as well as vocational training. It was agreed that any surplus funds would go into a reserve account. After 2015, there are plans to convert this reserve account into an endowment fund from which operations previously supported by institutional donors would be funded.

At the same time that funding from the endowment replaces income from institutional donors that is, the accounting period from 2015-2016 - the current annual cost base of TMI is planned to be cut to $\$ 510,000$. This represents a significant cut compared with the historic spending, and it represents approximately 60 percent of the average annual TMI expenditure from 2008 to 2013 on the education component alone. After 2015, it has been proposed that TMI activities focus on vocational training alone. Furthermore, the plan is to spend the entire endowment fund. 
Following the spend-down, it is proposed that TMT will be funded by profits from the new, wholly-owned private company Turquoise Mountain Trading Limited (TMTL).

\section{Cost Effectiveness}

Over the six-year period between 2008 and 2013, institutional donors were the primary source of revenues for TMT.

\section{Figure 3: TMT Revenue Shares from All Sources}

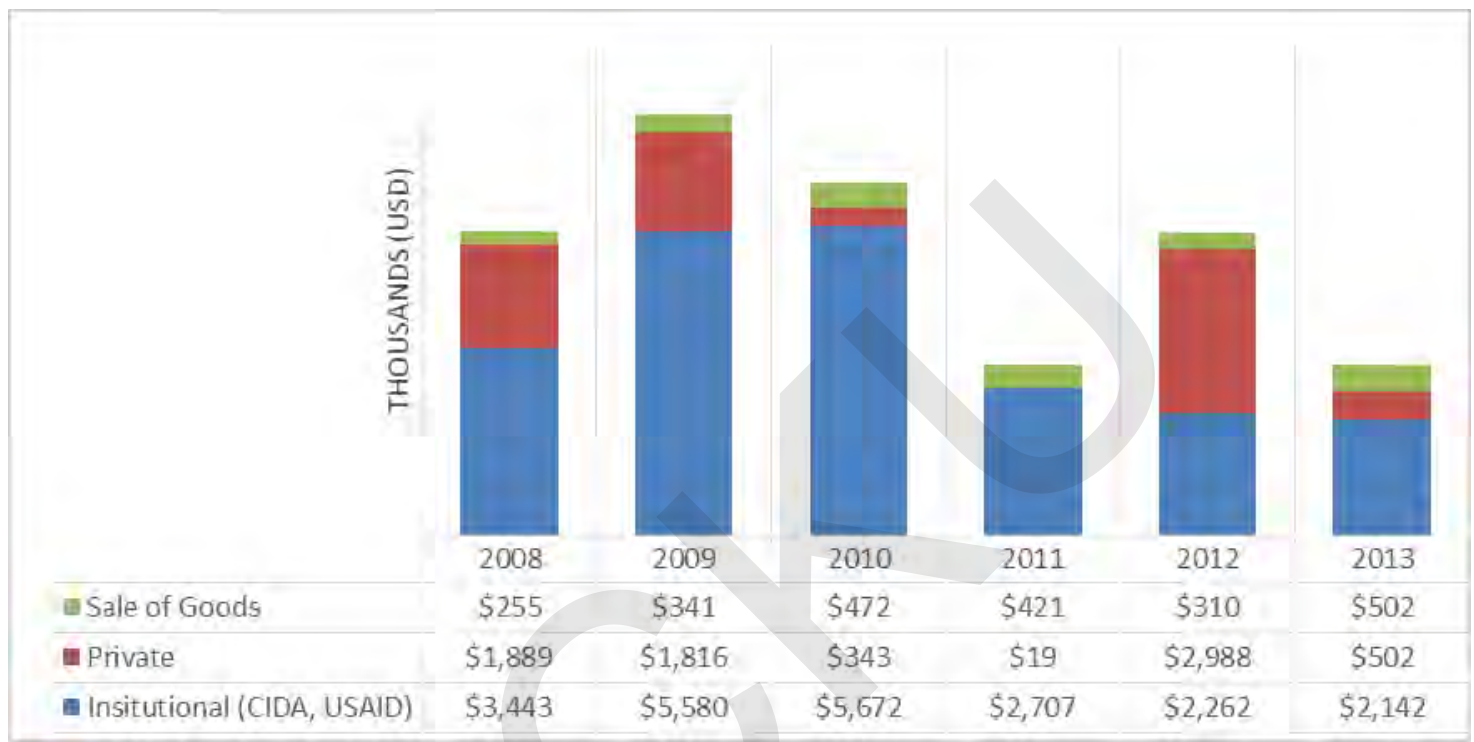

An indicator of cost-effectiveness and sustainability is whether TMT was able to adhere to its plan and fund its operations completely from institutional donor revenue. In practice, the use of reserve funds to make up a shortfall at the end of the financial year became an established pattern. Three times since 2008 TMT transferred funds from reserves of amounts over $\$ 100,000$. According to TMT financial statements, the amount in 2013 (\$1.98 million) transferred from reserves represented 45 percent of total expenditures. In 2011, 30 percent of expenditures were funded from reserves. 
Figure 4: TMT's Gross Transfer from Reserve (USD '000)

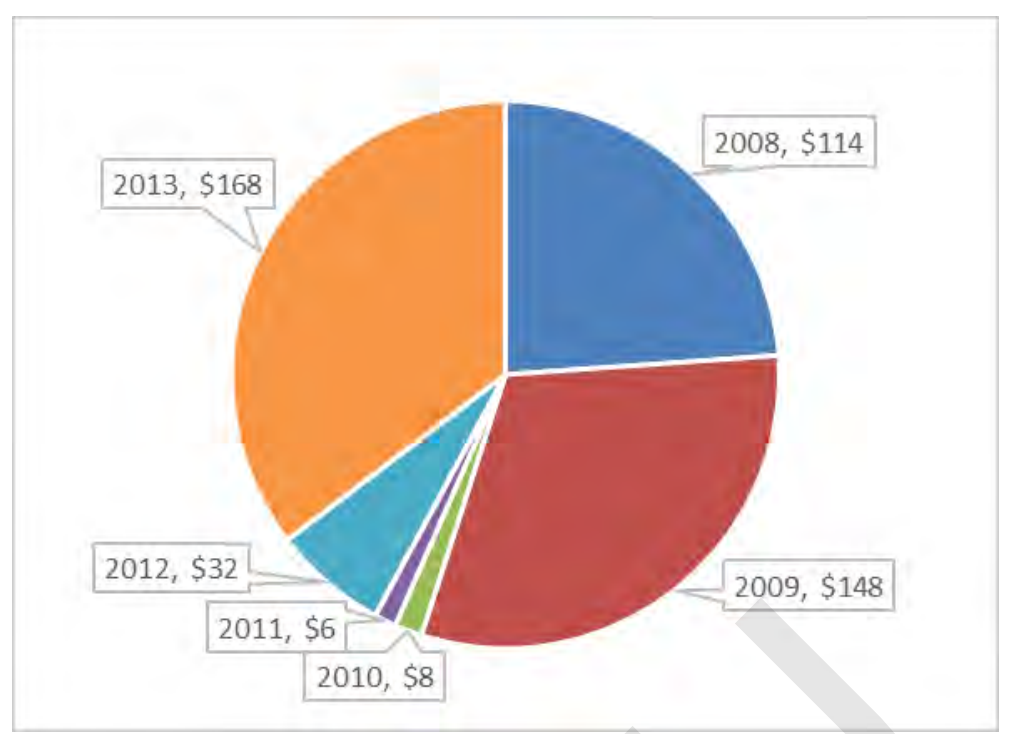

\section{GENDER}

The evaluation team was asked to consider whether male and female artisans and business people both benefitted from the BLT project. The evaluation team quickly established that, like almost all such projects in Afghanistan, TM reaches far more men than women. However, when recruiting new students, the management at TMI has been careful to maintain a balance of around 25 percent female enrollment - though this gender balance has recently slipped and the proportion of female students currently at the TMI is less than 20 percent. Figure 5 shows the gender bias towards the different vocational disciplines, with the vast majority of females opting for calligraphy, a small number in jewelry, and none in the other craft trades of woodworking and ceramics.

The evaluation team also looked at the extent that the BLT initiative benefited male and female workers at TM. The Institute has eight female and 57 male staff. Across the whole of TM's activities, women make up only 12.3 percent of all its employees. Five are teachers, one is a cleaner, one a business development assistant, and one a sales assistant. When recruiting new staff, every effort is made to encourage applications from women and shortlist them for interviews. Additionally, TM has established a women-friendly environment that has separate toilets, a separate dining hall, and sensitive teachers who are said to be encouraging girls to succeed. 


\section{Figure 5: Gender Balance of Current TMI Students in the Different Craft Disciplines}

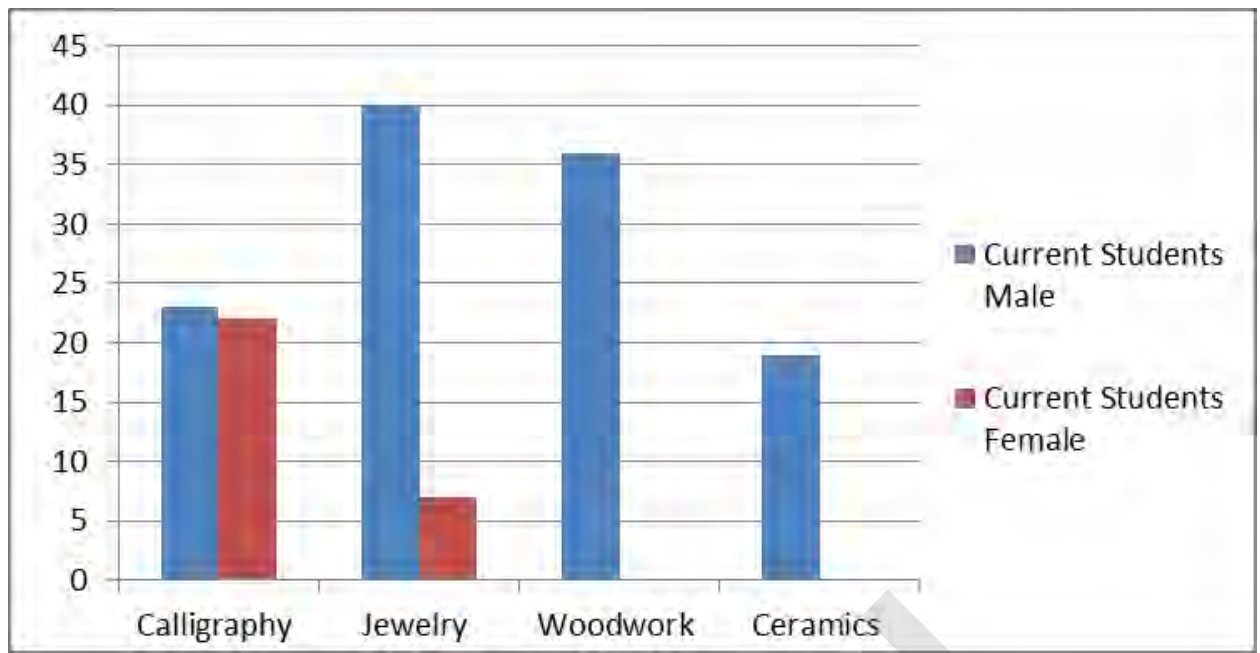

Of the 187 students who have graduated from TMI since 2008, 48 are women. Female students were mostly enrolled in calligraphy, 12 were in jewelry, and four graduated from woodwork. Currently, there are 147 students, out of which 29 are women, most of whom are enrolled in calligraphy. Only seven are in jewelry. Current female students make up only 19.7 percent of the overall class, which represents a decline in female enrollment. When recruitment takes place, TMI contacts all of the local girls' high schools, and female applicants are encouraged in general recruiting efforts. Last year, a Memorandum of Understanding (MOU) was signed with an organization called Women for Women to help any disadvantaged woman who may wish to become a student of TMI.

When students and teachers were asked why there were no female students currently in woodwork and ceramics, the response was these are not jobs for women; they are perceived to require heavy labor and women are not thought to be able to handle the machinery.

Among graduates of the TMI, 25 have started businesses, four of whom are women. Two female graduates have started calligraphy businesses and two are in the jewelry sector.

TM is currently supporting 20 businesses by giving them assistance in marketing their products and providing mentorship to enhance their business opportunities. Five of these businesses are owned by women. It should be noted that among these 20 businesses are several that are not owned and run by TMI graduates. 
Figure 6: Gender Balance of TMI Graduates in the Different Craft Disciplines

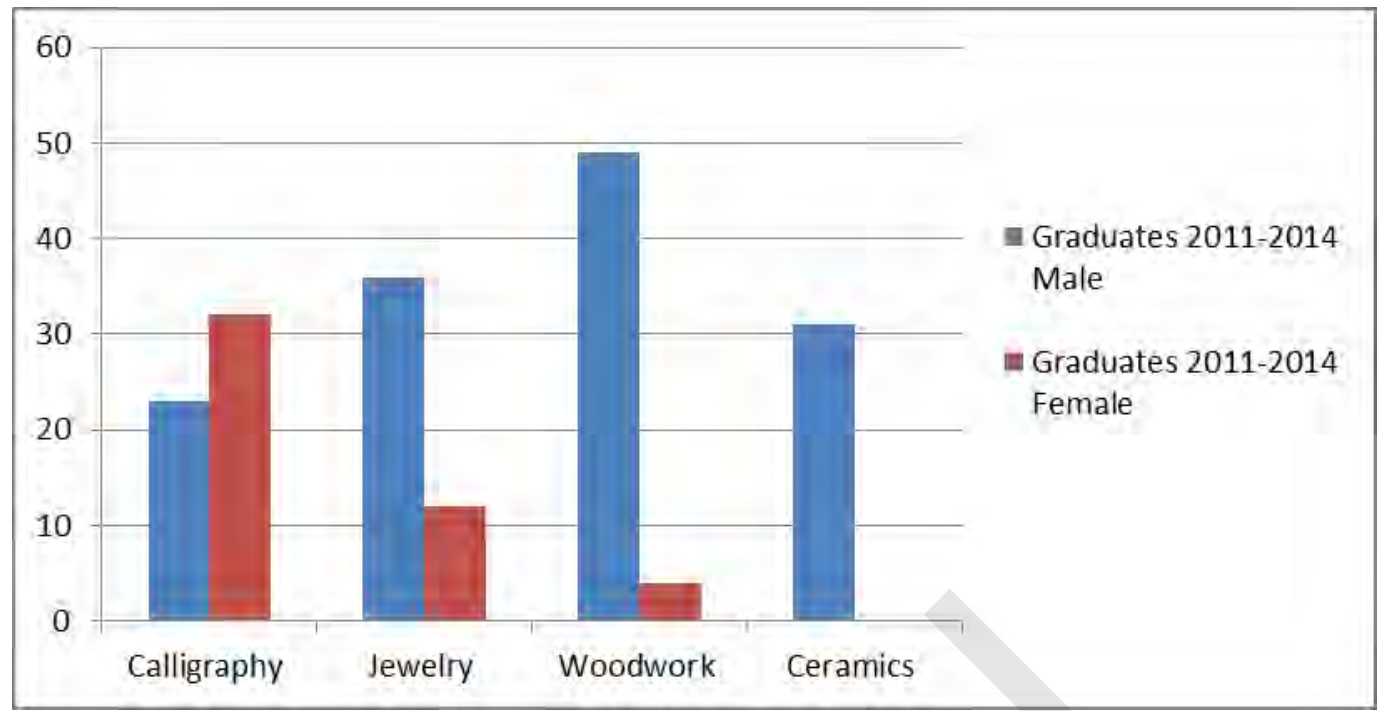

In practice, there is only a very small number of TMI graduate businesses that are able to provide the quality and consistency of their products demanded by international buyers. Notable among these companies is Blue Diamond, run by a pair of TMI male graduates from the class of 2012; and Muftah-e-Hunar Foundation, a highly successful calligraphy company that is owned by Samira Kitman, a female TMI graduate.

Figure 6 shows that the highest number of TMI students graduate from the Calligraphy Department. Two have started a business in that field. Depending on their order book, these female-owned and -run businesses provide additional employment to women on a casual parttime basis. Several participants in the female focus group discussion felt TMI should introduce more women to businesses and should make special provisions for women's needs in this regard.

\section{Sustainability Assessment Questions}

As the BLT program comes to an end, the evaluation team considered the extent to which TMI's operational costs are covered by existing or planned future revenue streams from sources other than USAID or other donors. The team examined the reliability and stability of the market-based revenue streams.

\section{INDEPENDENCE FROM DONOR FUNDING}

TMI's sustainability plan assumes that an endowment, formerly called the reserve fund, will replace revenues coming from institutional donors. Budget projections provided by TMI indicate, under one scenario, that the fund will be completely depleted in ten years. However, the 
historic pattern of having to draw upon reserves in each of the years from 2008 to 2013, as indicated in Figure 4, suggests that unforeseen expenses have regularly caused spending to be higher, or income lower, than the budget had forecast. In addition, based on financial data provided by TMT and TMI, the value of the reserve fund fell 16 percent, over 14 months, between December 2013 (\$5.1 million) and February 2015 (\$4.3 million).

This estimated yearly outflow of 13 percent from reserves during this 14-month period is another indicator of expenditure under-estimation on the part of TMT/TMI. Adding 13 percent to TMT's estimated expenditures ${ }^{3}$ over ten years, the endowment is projected to be depleted (based on TMT's own model) within seven years, rather than the ten year forecast. In other words, TMI is projected to be in a deficit position by 2024, given historical trends in expenditures. Moreover, the plan for establishing the new trading arm, Turquoise Mountain Trading Limited (TMTL), provides for a loan of an unspecified amount to be provided from TM funds. This is a short-term risk to outflows from the endowment fund, which is currently not accounted for in the budget projections.

The TMT financial statements reveal the intent of TMT trustees with respect to the use of the endowment fund: it is meant as an interim bridging fund until a more sustainable solution is evident.

The Trustees consider the main risk to be an inability to secure long term funding to allow the Trust to continue with its work. The Trustees have secured funding from USAID through to November 2015 and continue to build up unrestricted reserves to carry on activities up to $2030 .^{4}$

Given the position stated above, the bridging funding available from the endowment serves to span a transition period while TMTL becomes fully operational and profitable. Given the expenditure analysis above and the absence of a formal business plan for TMTL, there are many risks to the successful execution of TMT/TMI's sustainability plan.

\section{Sustainability and Cost-Effectiveness}

It is the judgment of the evaluation team that the average yearly budget (2008-2014) of $\$ 860,000$ is not an amount that will be sustainable in the future. The plans made by the TMT appear to concur with this judgment, since part of the TMT/TMI sustainability plan involves a reduction of the annual cost base of TMI to $\$ 510,000$. This budget level seems to be based on reasonable

\footnotetext{
${ }^{3}$ A conservative amount, based on the historical analysis of expenditures.

${ }^{4}$ TMT Report and Financial Statement: 2010 p. 2
} 
assumptions and was confirmed by an independent assessment of reasonable running costs for the TMI training.

In order to look at the long term feasibility and sustainability of the TMI on the basis of different assumptions, the evaluation team looked at the unit costs of producing a TMI graduate based on different scenarios.

Table 1 below indicates the unit cost of a TMI graduate on the basis of full- or part-time attendance with or without a stipend.

- Scenario 1 represents a full-time student enrollment of 100, over a three-year program, including a $\$ 50$ per month stipend for students.

- Scenario 2 is a variation of the first scenario where the total program length is shortened to two years and no stipend is paid.

- Scenario $2 b$ is a variant of 2 where students are asked to pay a fee to TMI to offset support costs.

- Scenario 3 varies from $2 b$ in that attendance of students drops to two days per week $(40 \%)$, and offers no stipend.

- Scenario $3 b$ varies from 3 in that enrollment rate drops to 50 and tuition is charged at a rate of $\$ 50$ per month.

Clearly, the most cost-effective solution is indicated by Scenario 3. This assumes a total student population of 100 with attendance at the Institute two days per week over a two year program, with the remainder of the time spent in employers' workplaces as apprentices. From the trainees' point-of-view, the additional benefit of spending time in the workplace is to provide them with a nominal wage as well as firsthand experience in a busy workplace. In most cases, it might be assumed that the students would be in a strong position to take up employment with the company where they had been apprenticed.

Table 2: Unit Cost of TMI Graduates with Alternative Assumptions and Cost Models

\begin{tabular}{|l|c|c|c|c|c|}
\hline & Scenario 1 & Scenario 2 & Scenario 2b & Scenario 3 & Scenario 3b \\
\hline Avg. Yearly Cost of Programme & $\$ 510,000$ & $\$ 510,000$ & $\$ 510,000$ & $\$ 510,000$ & $\$ 510,000$ \\
\hline $\begin{array}{l}\text { Yrly Stipend Given/Charged (+/-) or } \\
\text { Tuition Charged (-) }\end{array}$ & $\$ 36,000$ & & $-\$ 36,000$ & & $-\$ 18,000$ \\
\hline Cost per Full Time Student & $\$ 5,460$ & $\$ 5,100$ & $\$ 4,740.00$ & $\$ 5,100.00$ & $\$ 9,840.00$ \\
\hline Attendance Factor (1=Full Time) & - & - & - & 0.4 & 0.4 \\
\hline Cost per Part-time Attendance & - & - & - & $\$ 2,040$ & $\$ 3,936$ \\
\hline Total Cost, Length of Programme & $\$ 16,380$ & $\$ 10,200$ & $\$ 9,480$ & $\$ 4,080$ & $\$ 7,872$ \\
\hline Cohort Size & 100 & 100 & 100 & 100 & 50 \\
\hline Program Length (Yrs) & 3 & 2 & 2 & 2 & 2 \\
\hline
\end{tabular}




\section{Sustainable Public-Private Partnerships}

Since 2011, when the educational and training operations were consolidated at the Murad Khane site, the Turquoise Mountain Institute has been operating as an independent Afghan-run and legally-separate entity recognized by the Ministry of Education. The Turquoise Mountain Trust has continued to develop its role in working with local businesses and building an international client base for the sale of TM products.

In order to focus resources and income-generation on the TM's trading activities, the future funding of TMI is planned to be based upon charitable donations and a drawdown from the substantial endowment reserve over the next five years. The current energies of the senior leadership team, in seeking donor support and public-private partnerships, are strongly focused on a commercial and income-generating future. The extent of this change in emphasis is evident in the proposals to create the new wholly-owned company Turquoise Mountain Trading Limited. The company will be the vehicle through which profits are generated, and its existence as a separate legal entity will allow greater freedom and flexibility within the income-generating activities.

The creation of the commercial trading arm based on TM's strong track record and quality reputation is possible through forming and developing public-private alliances with international commercial partners. For example, TM has worked with a number of international jewelry brands based in London and New York, such as Pippa Small, Hattie Rickards, Zara Simon, Kate Spade, and Bajalia. In woodworking and carpentry, an alliance has been formed with Peter Pennoyer Architects; and, in a departure from TM's foundational artisanal trades, alliances are being formed for the sale of carpets from several Afghan regions, as well as glassware from Herat. The list of commercial partnerships is impressive, and on the basis of the established sales from TM and its current Afghan partners of not less than \$1 million per year, the prospects for these enterprises look bright.

It must be noted, nonetheless, that the prospect of a new and exciting trading dimension has tended to take the attention, energy, and day-to-day commitment of the senior leadership team away from the very foundation of TM in Murad Khane. It is, of course, a great thing to be generating an international market for Afghan products, but as was noted earlier in the report, there is always a tension between the demands of the market and the preservation of ancient crafts and skills. The two are not entirely incompatible, but the next five-year plan risks taking $\mathrm{TM}$ in the direction of commercialism rather than conservation.

None of these developments in and of themselves should be seen, necessarily, as an overwhelming threat, but the focus of the senior leaders is being taken into commercial directions of which few of them have any direct experience. At the same time, the operations of the TMI are in need of a radical review and re-evaluation. Even with the proposed reduced cost base of approximately $\$ 500,000$ per annum, the cost of educating students remains extremely 
high, particularly when it is clear that, currently, more than half of them do not continue into any sort of employment in the craft trades.

Education enterprises, particularly in vocational and higher education, in many parts of the world are nowadays frequently recognized as profit rather than cost centers. The huge expansion of private universities in Afghanistan in recent years is evidence of the willingness of families to pay for an education, which they see as a pre-requisite for gaining a good job. Divorcing TMI's operations for it to operate as an entity independent of TMT, and having it funded by a generous endowment, runs the risk of it ceasing to be innovative and sufficiently attuned to market needs. For the Institute to be a sustainable operation moving into an uncertain future, it needs to take careful stock of its education and training, and of its relationship with its customers - the smallto-medium enterprises where TM students will seek employment on graduation.

The senior leadership of TMT, which has ultimate oversight of TMI, must take heed of the capacity to generate income through, for example, running short courses on a full cost-recovery basis; offering fee-paying postgraduate studies; and seeking research commissions from international institutes. If the business model of the Institute recognized the need to reduce its cost bases and take account of its potential for income generation, then it could look to a more sustainable future that is less dependent upon an endowment for its long-term security.

As part of the ambitious plans for future trading opportunities for TMTL, there are proposals for promoting 'Brand Afghanistan', especially among the international ethical trading community. This is, indeed, a laudable ambition, but at present there are no explicit plans as to how TMTL will coordinate with the local Afghan-based trade entities, such as the Afghanistan Chamber of Commerce and Industry (ACCI) and the Export Promotion Agency for Afghanistan (EPAA); nor are there any plans explaining how TMTL will cooperate with the other organizations that are exporting Afghan craft products, such as the NGO Zardozi or Saleh Fine Silks, or the myriad of companies currently trading in Afghan carpets. For the international marketing of 'Brand Afghanistan' to be credible and inclusive, strong working relationships with all of these parties should be seen as a pre-requisite to the realization of a broader and deeper ambition to promote the products from Afghan arts and handicrafts industries more generally.

\section{QUALITY EMPLOYMENT OPPORTUNITIES}

The Afghan businesses that TMT supports fall into two categories, as follows:

\section{Enterprises established by graduates or TM associates}

Most of the graduates who have established enterprises are highly motivated young Afghan men and women. They have established these enterprises with the hope of receiving a lot of support from TMT, but their lack of business awareness is a significant handicap to their capacity to 
operate with any degree of independence from TMT. Their sketchy knowledge of business practices includes weaknesses in the following areas:

- Business planning - presenting a business case to backers; demonstrating the viability of their business and showing realistic growth forecasts.

- Understanding of the market and market planning - for many businesses TMT is doing almost all of the marketing and planning. Many of the fledgling companies are not aware of the processes through which they receive orders; in the absence of TMT several companies would not be sustainable

- Financial planning - most graduates have a weak understanding of key business processes, such as supply chain management, the cost of inventory maintenance, cashflow forecasting, and the need to constantly search for new markets.

- Customer relationship management - customer relationship skills are underdeveloped and few graduates have a good understanding of the need to maintain client relationship management databases.

- Sub-contracting and quality assurance - few of the small companies are able to accommodate a sudden influx of major orders for multiple items; their workforces are typically very small. Although within the ecosystem of TM graduates there is a reservoir of expertise, assuring the quality to consistent standards across multiple sub-contractors is problematic.

Despite the tribulations and poor preparation that many graduates claim to have received to help them thrive in the highly-competitive international marketplace, a few businesses have succeeded in establishing and sustaining their operations, often through the personality, skills, and perseverance of the individual proprietors. Two case studies of successful businesses operated by single-minded and determined graduates are presented below.

\section{Case Study 1 - Blue Diamond Jewelry}

Blue Diamond Jewelry is a business started by three graduates of TMI in 2012. They since have recruited four more graduates, and TMI is currently providing them marketing and sales support. The jewelry that they produce is of high quality and finds a ready market through TMT. Most of their current sales are taking place through TMT's orders, but the owners are well-prepared to do their own marketing and attend trade fairs and exhibitions to seek new markets and to increase their direct sales.

Another model of business support by TMT is the woodworking operation of Atelier UN. The proprietor is a former teacher from TM. The extensive workshops located near Babur Gardens are used to prepare major set-piece commissions and high-quality carving and fret-work. TMT 
supports the business both in terms of a rent subsidy and marketing, and the chief operating officer is a former teacher at TMI. Ten of the 20 full-time workers there are TMI graduates. Sixty percent of the sales are said to originate through TM orders, but the proprietor is able to generate the remainder through his own offices. Because he is willing in the long run to make this company self-reliant, he suggested TM gradually decrease the amount it is paying for the company's expenses.

\section{Enterprises that exist independently of TM}

The second category of businesses that TMT supports is long-established Kabul companies. Some of these establishments are older than TM itself. They have their own customer base and their own networks to generate and maintain sales orders. TMI's graduates are of some value to these companies, but they also have trained workers in their own fields of business: ceramics, jewelry, and woodwork.

One example the evaluation team visited is MMCC Carpentry, where TMI had placed two apprentices for two months of work experience last year. This company has been established for 50 years and is currently working on a large order from the Indian Embassy for the new parliament building. The proprietor pointed out the importance of English-language skills among graduates, not least to operate the computer-controlled woodturning machinery, with instructions in English.

Another example is the jewelry and ceramics company Jamal Gem Cutting. This company has been in operation for more than 70 years, with Haji Abdul Karim, the owner, saying his family has kept Afghan art alive through their work. Photographs of his forefather with King Zaher Shah hang on his walls. This company had also provided space for two TMI apprentices last year.

In the case of both of these companies, they were happy to take TMI students as apprentices, and would be happy to do so in the future and pay them a small wage. The proprietors expressed some surprise that the students who had spent some time with their companies did not appear to be strongly motivated to work in their particular craft trade. The observation was made that if the students had been exposed to the realities of working in the industry from the start of their program at TMI, then they may have been in a better position to decide about their own ambitions and choice of career.

Several small start-up companies expressed concern about fair and equitable communication from the Business Development Unit at the Institute. They felt not all companies were equally favored, and that one or two companies receive special treatment when big orders have to be filled. These perceptions are almost certainly true. The demands of the market for quality and consistency often mean that, if there is a tight deadline, the tried and tested suppliers will be 
relied upon at the risk of neglecting and nurturing new companies. These are the sorts of pressures that TM will need to reconcile as it increasingly looks to fill the order books with large and repeat businesses from, especially, jewelry traders in Europe and North America.

\section{Case Study 2 - The Muftah-e-Hunar Foundation}

The Muftah-e-Hunar Foundation was established in 2010 by TMI calligraphy graduate, Samira Kitman. Kitman thinks TMI equally encourages men and women to work in their fields of interest and establish their own businesses, but she feels that some of the women are not well-motivated to do so, and that is why the number of female graduates working or starting a business is fewer than the number of men.

Kitman employed 32 people last year as she was trying to deliver around 500 calligraphy and painting pieces for a large hotel commission in Mecca, Saudi Arabia. This year, she has only five employees and is receiving between three-to-five orders a month, with 50 percent of these orders coming through TM. Her greatest business challenge is marketing and sales. She says "if TM doesn't support its graduates to get orders, such as Mecca's, these businesses will remain small or will collapse, as it is very difficult to find markets for art work in Afghanistan." Although she has some plans to combine calligraphy and miniature work with other work, such as furniture or dishes, and establishing an online sales outlet, finding markets and orders to generate enough revenue remains her major concern.

\section{CONCLUSIONS}

Turquoise Mountain Trust, in its almost nine years of operation, has achieved some remarkable successes. Its transformation of the Murad Khane area of Kabul is testament to the vision, determination, and the strong ethos of conservation and rehabilitation on which the Trust was founded. The vocational training of the Turquoise Mountain Institute has provided many young people, particularly those from poor socio-economic backgrounds, with some viable craft skills through which to make a living.

Nonetheless, in the seven years during which TMT has been receiving funding from USAID, the climate for TVET has been transformed in Afghanistan through successive waves of donor funding. Both standards and expectations are now much higher. Therefore, as the funding, which is represented by the BLT initiative, draws to its conclusion in November 2015, the time is ripe for a reappraisal of the objectives and priorities at the Trust. Ambitious plans exist for the establishment of a new wholly-owned private company through which the trading of TMsourced artisanal products can be facilitated. At the same time, it is proposed that the TMI will be funded by a draw-down fund for approximately five years until the trading arm of TM will be 
able to support the Institute from its profits. The conclusion of this consultancy team is that these plans for the future should be revisited in the light of the findings of this report.

The evaluation team concluded:

- The cost of vocational training at TMI is unsustainably high.

- The current training offered is of low quality and graduates are not job- or market-ready.

- The TMT priorities are currently focused on trading and market development.

- The supply chain to support this market is very fragile.

- The rehabilitation work is valuable and must be protected; community relations are key.

A reevaluation of the priorities for the Trust for the next five-to-ten year period would be to the benefit of all stakeholders so that the impressive achievements over the past decade can be reinforced and amplified over the next phase of development.

To conclude, it is fitting that a quotation from one of the supporters and international partners is shared in full. These words encapsulate the love and gratitude of so many people who have worked to help in the realization and sustenance of this truly remarkable project of Turquoise Mountain that has become an institution.

... It is not whether TM should exist or not - they need to, but how USAID structures the right partnership with them that helps TM focus on their core strengths, namely being on the ground, having the relationships with artisans.

- An international trading partner of Turquoise Mountain, June 2015

\section{RECOMMENDATIONS}

- The Board of Trustees (BOT) should conduct a thorough review of the quality of the programs and activities at the TMI so that they are delivered to the highest standard and in the most cost-effective manner, and so the skills of the graduates are more closely aligned to labor market needs. The review needs to assess the viability of TMI as a mixed-economy learning establishment with, for example, full- and part-time craft programs; short course delivery to businesses and the local community; postgraduate research; and international collaboration with vocational colleges, universities, and institutes of higher education.

- The management at TMT and the BOT must ensure that ambitious plans for the commercial developments of the Trust, with the formation of an independent for-profit trading arm, do not become a distraction to the core purpose and principles upon which TMT was founded. In particular, TMI should be kept under constant scrutiny and review to ensure that the courses are suitable to prevailing market conditions, are of high quality, and are aligned to students' and employers' needs. 
- On the basis of TM's declared aim to build a strong Afghan brand through international market recognition, the management should work with other NGOs and local Afghan agencies to play a greater role, collectively, in the quality assurance and collaborative marketing of the products of 'Brand Afghanistan.' TM is well-placed, through its reputation and independence, to authenticate and verify many of the indigenous arts and craft products and, in particular, gemstones. The formation of an independent laboratory for gemstone and materials testing and verification is an example of one tangible way in which TM could use its good offices for the greater good of Afghanistan trade.

- TM should re-examine relationships and communication with the Murad Khane community, keeping in mind that the community is not static. Periodic efforts to update the community - both men and women - are important to containing the spread of misinformation and managing expectations. At the same time, it may be worth examining whether favoritism affects relationships with the community and how it can be curtailed. TM might consider additional monitoring methods to ensure that resources are being fairly distributed.

- TM should consider working with the community to draft written responsibilities so that it is clear what TM will do to assist with the maintenance of structures, garbage collection, drainage, and other essential services, and for what the community and/or shura is responsible. Consulting the Ministry of Culture and Information in the process is also advised, as it currently has responsibility for historical city preservation.

- TM should re-examine relationships and communication with the Murad Khane community. Keeping in mind that some community members are new, periodic efforts to update the community - both men and women - are important to containing the spread of misinformation and managing expectations. At the same time, it may be worth examining whether favoritism affects relationships with the community and how it can be curtailed. TM might consider additional monitoring checks to ensure that resources are being fairly distributed.

- TM should consider working with the community to draft written responsibilities so that it is clear what TM will do to assist with maintenance of structures, garbage collection, drainage, and other essential services, and for what the community and/or shura is responsible. Consulting the Ministry of Culture and Information in the process is also advised, as they currently have responsibility for historical city preservation. 
ANNEX I: SCOPE OF WORK

OFFICE OF ECONOMIC GROWTH AND INFRASTRUCTURE (OEGI)

\&

OFFICE OF PROGRAM AND PROJECT DEVELOPMENT (OPPD)

JOINT STATEMENT OF WORK FOR THE

FINAL PERFORMANCE EVALUATION AND SUSTAINABILITY ASSESSMENT

OF

BUILDING LIVELIHOODS AND TRADE (BLT)

\section{PROGRAM INFORMATION}

\begin{tabular}{|l|l|}
\hline Program/Project Name: & $\begin{array}{l}\text { "Regenerating Murad Khane, Restoring, Refurbishing, and Revitalizing } \\
\text { the Old City District of Kabul," renamed "Building Livelihoods and } \\
\text { Trade" in 2010 }\end{array}$ \\
\hline Contractor: & Turquoise Mountain Trust \\
\hline Contract \#: & AID-306-A-00-08-00503-00 and AID-306-A-00-09-00503-00 \\
\hline Total Estimated Cost: & $\$ 10,637,111$ \\
\hline $\begin{array}{l}\text { Life of } \\
\text { Program/Project: }\end{array}$ & November 2, 2008- November 1, 2015 \\
\hline Active Provinces: & Kabul \\
\hline $\begin{array}{l}\text { Mission Development } \\
\text { Objective (DO): }\end{array}$ & DO 1: Sustainable Agriculture-led economic growth expanded \\
\hline $\begin{array}{l}\text { Linkage to Standard } \\
\text { Program Structure } \\
\text { (SPS): }\end{array}$ & \multicolumn{2}{|l|}{} \\
\hline Required? & $\begin{array}{l}\text { Not required, but needed for learning purposes and to assist the } \\
\text { Implementing Partner consider long-term sustainability. }\end{array}$ \\
\hline Public or Internal: & Public \\
\hline
\end{tabular}

\section{INTRODUCTION}

Turquoise Mountain Trust (TMT), a British-registered non-profit, was founded in 2006 with the vision of restoring the historically and architecturally significant community of Murad Khane in central Kabul. TMT assists the community to access health care and primary education, and with revitalizing Afghan arts. Initially, TMT gained community support through an intensive effort to clear trash that had accumulated over decades, by restoring crumbling buildings (to date, over 90 structures have been rehabilitated), and by installing water drainage and sanitation systems. TMT also started a community clinic and primary school in Murad Khane, and then registered the Afghan non-profit, Turquoise Mountain Institute (TMI) for Afghan Arts and Architecture, to 
train young people in the areas of woodwork, ceramics, calligraphy and miniature painting, and jewelry and gem-cutting.

In November 2008, USAID approved the \$6,099,465 for "Regenerating Murad Khane, Restoring, Refurbishing, and Revitalizing the Old city District of Kabul" Cooperative Agreement (AID-306-A-00-08-00503-00) with Turquoise Mountain Trust. The agreement covered four elements: urban regeneration, community development, education, and business development. In September 2010, the Cooperative Agreement was renamed "Building Livelihoods and Trade (BLT)" (AID-306-A-00-09-00503-00) and extended to November 1, 2015. The Total Estimated Cost (TEC) was also increased by $\$ 4,537,646$, bringing the total to $\$ 10,637,111$. Three of the elements - urban regeneration, community development, and business development—were completed in July 2011, leaving only the fourth element - education-for continued support to the end of the program. The education element is centered on the training provided by TMI.

\section{BACKGROUND}

The objectives of the BLT program are to provide ongoing education and training, expand economic opportunities, and strengthen livelihoods of students and artisans in the handicraft sector of Afghanistan. The program aims to:

(1) Build economic and trade opportunities for Afghans through the economic, social, and cultural regeneration of Murad Khane, a traditional commercial and craft neighborhood in the center of Kabul's Old City;

(2) Provide traditional craft education through TMI; and

(3) Develop the market for Afghan crafts domestically and abroad through businessdevelopment activities.

The following are key activities of the BLT program:

- Revive and restore the threatened artistic heritage of Afghanistan;

- Provide support to TMI so that high-quality Technical Vocational Education and Training (TVET) will be available to young men and women (140 students were enrolled last term) over three years of study. In FY2014, a curriculum review was undertaken to improve the quality of training. Students graduate with a TVET degree accredited by the Ministry or Education, as well as a British City and Guilds certificate; and

- Provide livelihood opportunities for TMI students and graduates in the handicrafts sector. Through contacts with domestic and international clients, TMF and TMI direct handicraft orders to its graduate businesses for production. For example, when Turquoise Mountain gets a contract to make jewelry for American designer, Kate Spade, or to create customized calligraphy for a hotel in Mecca, it draws on the expertise of its students, graduates, and others to fill the order.

\section{PROGRAM GOALS AND OBJECTIVES}


The mission statement of Turquoise Mountain Trust (TMT) is to regenerate Afghanistan's traditional crafts and historic areas, and in so doing create jobs, skills, and a renewed sense of national identity. The objectives of TMT are to provide on-going education and training, economic opportunities and livelihoods, and create in the center of Kabul a symbol of Afghanistan's rich cultural heritage as a driver for the country's future prosperity. The strategic objectives of TMT fit into USAID assistance objective to "develop a business climate that enables private investment, job creation, and financial independence," associated intermediate result, "workforce meets private and public sector demands," and sub-intermediate result "Market-led technical and vocational education and training provided through private and public sector TVET schools" (See the results framework below).

\footnotetext{
\begin{tabular}{|l|} 
Key \\
AO Assistance \\
Objective \\
IR Intermediate Result \\
PI Performance \\
Indicator \\
\hline
\end{tabular}

AO4: A developed business climate that enables private investment, job creation and financial independence *

IR 4.4: Workforce meets private and public sector demands *

Sub-IR 4.4.2: Market-led Technical and Vocational Education and Training (TVET) provided through private and public sector TVET schools *

Critical Assumptions

1. Security situation in Kabul remains conducive

2. TMT retains support of stakeholders

3. Government remains in support of private sector arnixth

PI 4.4.1 Number of persons receiving new employment or better employment (including better self-employment) as a result of participation in USG-funded workforce development programs $\wedge$

PI 4.4.2 People completing USGfunded market-driven TVET programs *

* From U.S. Foreign Assistance for Afghanistan, Post Performance Management Plan 2011-2015, Volume 1, Summary

${ }^{\wedge}$ From F Indicator master list

PI 4.4.3 People transitioning to further education and training within six months after participation in USGfunded TVET programs *

PI 4.4.4 Full time equivalent students in USG-funded TVET programs
} 


\section{PURPOSES OF THE EVALUATION \& SUSTAINABILITY ASSESSMENT}

As the BLT program is in its seventh and final year, it is important to investigate the successes and challenges of the program, especially in light of the fact that in March 2015, TMT received a new grant from USAID to put on an exhibition at the Freer/Sackler Galleries in Washington D.C. in 2016 (AID-306-G-15-00003); and in March 2015, TMT submitted an unsolicited concept paper for five more years of funding. This Statement of Work includes both a final evaluation of the BLT program and a sustainability assessment of TMF, TMI, and the Afghan craft enterprises that employ many of its TVET graduates and with which the Institute collaborates.

\section{Final Performance Evaluation}

The purpose of the BLT final performance evaluation is to assess (1) the extent to which economic and trade opportunities for Afghans have been built through the program's initiatives for the economic, social, and cultural regeneration of Murad Khane, a traditional commercial and craft neighborhood in the center of Kabul's Old City, (2) the quality of the traditional craft education the program has provided through TMI, and (3) the effectiveness of the program's efforts to market Afghan crafts domestically and abroad through businessdevelopment activities. Specifically, it will achieve the following:

(1) Evaluate the progress of BLT in achieving its goals and expected results and targets from 2008 to present. The team will also report any findings that pertain to the previous USAID project.

(2) Identify lessons learned and make necessary recommendations on the design, implementation, and management for incorporation into similar future programming.

The results of the BLT final evaluation will be used for USAID accountability and learning purposes, and will give TMT and TMI a clear indication about the effectiveness under their management of USAID resources. USAID Management will institute recommendations deemed feasible within the ongoing program and in the design of any new program or program components.

\section{Sustainability Assessment}

TMI's heavy reliance on USAID funding makes the Institute vulnerable in the context of declining USAID resources. It is important that TMI increase and diversify revenues while making an effort to contain its capital and operating costs. Sustainability will have been achieved when TMT and TMI have the ability to maintain project results and impacts without relying on USAID funding. While TMT has taken positive steps, including seeking private, philanthropic contributions with a view towards building an endowment and selling handicrafts produced by TMI students, graduates, and others to international buyers, the assessment will look at the extent to which the institute can be sustained by these means in the long term. The sustainability assessment has three objectives:

(1) Estimate both resource and cost containment that will be required in order for TMI to achieve its strategic institutional goals. 
(2) Examine revenue streams that can contribute to the long-term financial sustainability of the institution.

(3) Assess the long-term viability of the business model of TMT, TMI, and its network of collaborating Afghan handicraft enterprises.

The results of the BLT Sustainability Assessment will provide TMT and TMI with an expert external perspective on its progress towards self-sufficiency and give clear recommendations for their consideration. It will also be considered by USAID Management as ongoing support to TMT and TMI is contemplated and give broader insight into how to work effectively with similar non-profits in Afghanistan.

\section{EVALUATION \& ASSESSMENT QUESTIONS}

The investigation of BLT will be comprised of two distinct components: (1) a final evaluation of seven years of USAID program management, and (2) a sustainability assessment of TMI and the Afghan handicraft enterprises with which it works.

Final Evaluation Questions:

(1) Livelihoods: To what extent has the program activities/initiatives contributed to increasing the economic opportunities for Afghan artisans and businesses?

(2) Trade: How effective has the program been in improving the ability of beneficiaries (students, artisans, and businesses) to market crafts domestically and abroad?

(3) Quality: To what extent has the program increased the quality of products produced by project beneficiaries (students, artisans, and businesses)?

(4) Rehabilitation: How satisfied is the target community with the neighborhood rehabilitation efforts initiated by TMT/TMI and are the results sustainable?

(5) Cost: To what extent was TMI's three-year TVET program a cost-effective means of educating male and female handicraft professionals that are demanded by the Afghan market?

(6) Gender: To what extent has BLT benefitted both male and female artisans and business people?

Sustainability Assessment Questions:

(7) As the BLT program comes to an end, to what extent are TMI's operational costs covered by existing or planned future revenue streams from sources other than USAID or other donors? Please examine reliability and stability of any marketbased revenue streams.

(8) Can the current structure of TM-including TMT, TMI, and all partner organizations - be mobilized to create a fully sustainable and profitable public- 
private partnership and business venture that is capable of meeting the objectives of (a) creating a strong Afghan "brand", (b) establishing wide-market presence, and (c) generating robust domestic and overseas sales?

(9) To what extent are the Afghan handicraft enterprises with which TMT and TMI collaborate sustainable, independent, and business-savvy organizations that are capable of providing quality jobs to male and female graduates of TMI and ensuring adequate revenue streams?

\section{DESIGN \& METHODOLOGY}

The Evaluation Team will develop an approach to assess the different aspects of the program to comprehensively answer the questions. Though the team has discretion to design and use the most appropriate evaluation tools, the approach should be participatory in both design and implementation. Close coordination with USAID/Afghanistan's Office of Project and Program Design (OPPD) and Office of Economic Growth and Infrastructure (OEGI) will be necessary to ensure that the Evaluation Team selects methods that are suitable for use in conflict areas. Evaluation techniques may include document review, field interviews with beneficiaries and non-beneficiaries, and focus group discussions, among others. The Evaluation Team can use a mix of data collection and analysis methods to generate descriptive, evidence-supported answers.

USAID prefers quantitative methods and random sampling, to the extent possible. The proposed evaluation design and methodology will be critically evaluated against the "purpose of the evaluation', most importantly in its ability to provide actionable guidance to USAID for future programing. A range of documents (see Section VIII below) will be provided by USAID/OEGI to the Evaluation Team for review, prior to arriving in country. The OPPD Point-of-Contact is the SUPPORT II Contract Officer's Representative (COR) Daryl Martyris and the OEGI Point-of-Contact is the BLT Agreement Officer's Representative (AOR) R. Paul McKee and BLT Alternate AOR Mohammad Shiwani.

Following is a table that suggests data sources and collection and analysis methods that may be used by the Evaluators when approaching the nine evaluation/sustainability assessment questions:

\section{EXISTING PERFORMANCE INFORMATION SOURCES}

The following is an illustrative list of initial documents that will be provided to the Evaluators:

1) BLT Cooperative Agreement

2) BLT Statement of Work

3) BLT Work Plans

4) BLT M\&E Plan

5) BLT Monthly and Annual Reports (at least the four most recent)

6) BLT Fact Sheet

7) BLT development strategy and/or sustainability plan (if any)

8) BLT financial record

9) Other documents as requested and deemed necessary 


\section{EVALUATION TEAM COMPOSITION}

The Evaluation Team shall include evaluation and technical specialists with relevant experience particularly in TVET and Small and Medium Enterprise (SME) development in a conflict/post-conflict country. The team shall include an expatriate expert and two Afghan professionals with strong interpersonal and writing skills and cultural awareness. Below are the requirements for the team.

- Evaluation Team Leader (Expat). The Team Leader (TL) shall be an evaluation expert with at least seven years of program evaluation experience preferably with USAID-funded TVET programs and Small and Medium Enterprise (SME) development. S/he shall possess excellent leadership and report writing skills, and be able to work well with others. The TL shall possess a Master's degree in economics, finance, TVET, international development, social science, or a related discipline. The TL should be able to write a high-quality, standard, accurate, and concise report in English. Afghanistan or regional country experience is preferred.

- Financial Analyst (Afghan). The Financial Analyst will have experience in finance and/or accounting and familiarity with analysis using Excel. S/he should be experienced with budget analysis, cost comparison techniques, and producing graphs and tables. S/he must be fluent in Dari and/or Pashto, with good English skills.

- Evaluation Assistant (Afghan). The Evaluation Assistant will work under the direction of the Team Leader to collect data and support focus group discussions.

\section{EVALUATION SCHEDULE}

The following is the illustrative Level of Effort (LOE) for the BLT Evaluation Team Lead:

\begin{tabular}{|l|c|c|c|}
\hline Activity & Expat TL & $\begin{array}{c}\text { Financial } \\
\text { Analyst }\end{array}$ & $\begin{array}{c}\text { Evaluation } \\
\text { Asst }\end{array}$ \\
\hline $\begin{array}{l}\text { Document review/ work plan } \\
\text { development }\end{array}$ & 4 & 2 & - \\
\hline Travel to/from Afghanistan & 4 & - & - \\
\hline & & & - \\
\hline & - & - & 23 \\
\hline Interviews \& drafting report & 23 & 23 & 1 \\
\hline Exit brief & 1 & 1 & 1 \\
\hline Final draft/respond to comments & 3 & 2 & 25 \\
\hline
\end{tabular}

\section{DELIVERABLES AND REPORTING REQUIREMENTS}


1. In-briefing: Before arriving in Kabul the Evaluation Team will have an in-briefing with the OPPD M\&E unit and the OEGI Team for introductions and to discuss the team's understanding of the assignment, initial assumptions, evaluation questions, methodology, and work plan, and/or to adjust the SOW, if necessary.

2. Evaluation Work Plan: Before travelling to Kabul, the Evaluation Team Leader shall provide a detailed initial work plan to OPPD's M\&E unit and OEGI. The initial work plan will include: (a) the overall evaluation design, including the proposed methodology, data collection and analysis plan, and data collection instruments; (b) a list of the team members and their primary contact details while in-country, including the e-mail address and mobile phone number for the Team Leader; and (c) the team's proposed schedule for the evaluation. USAID offices and relevant stakeholders are asked to take up to two days to review and consolidate comments through the SUPPORT II COR. Once the Evaluation Team receives the consolidated comments on the initial work plan, they are expected to return with a revised work plan within two days. The revised work plan shall include the list of potential interviewees and sites to be visited.

3. Mid-term Briefing and Interim Meetings: The Evaluation Team is expected to hold a mid-term briefing with USAID on the status of the assessment, including potential challenges and emerging opportunities. If desired or necessary, weekly briefings by phone can be arranged.

4. PowerPoint and Final Exit Presentation: The Evaluation Team is expected to hold a final exit presentation to discuss the summary of findings and recommendations to USAID. This presentation will be scheduled as agreed upon during the in-briefing. Presentation slides should not exceed 18 in total.

5. Draft Evaluation Report: The draft evaluation report should be consistent with the guidance provided in Section XIII: "Final Report Format." The report will address each of the issues and questions identified in the SOW and any other factors the team considers to have a bearing on the objectives of the evaluation. Any such factors can be included in the report only after consultation with USAID. The submission date for the draft evaluation report will be decided upon during the mid-term or exit briefing and submitted to OPPD's M\&E unit by Checchi. Once the initial draft evaluation report is submitted, the following deadlines should be followed:

a. OEGI will have eight working days in which to review and comment on the initial draft, after which point USAID/OPPD's M\&E unit will have two working days to review and consolidate all USAID comments (total of 10 working days). OPPD will submit the consolidated comments to Checchi.

b. The Evaluation Team will then have five working days to make appropriate edits and revisions to the draft and re-submit the revised final draft report to USAID.

c. OEGI and the M\&E unit will have 10 working days after the submission of the second revised draft to again review and send any final comments.

6. Final Evaluation Report: The Evaluation Team will be asked to take no more than three days to respond/incorporate the final comments from the OEGI and OPPD. The Evaluation Team Leader will then submit the final report to OPPD. All project data and records will be submitted in full and should be in electronic form in easily readable 
format; organized and documented for use by those not fully familiar with the project or evaluation; and owned by USAID.

\section{MANAGEMENT}

Checchi/SUPPORT-II will identify and hire the Evaluation Team, pending the BLT AOR's concurrence and AO approval, assist in facilitating the work plan, and arrange meetings with key stakeholders identified prior to the initiation of the fieldwork. The Evaluation Team will organize other meetings as identified during the course of the evaluation, in consultation with Checchi/SUPPORT-II and USAID/Afghanistan. Checchi/SUPPORT-II is responsible for all logistical support required for the Evaluation Team, including arranging accommodation, security, office space, computers, Internet access, printing, communication, and transportation.

The Evaluation Team will officially report to Checchi's SUPPORT-II management. Checchi/SUPPORT-II is responsible for all direct coordination with USAID/Afghanistan/OPPD, through the SUPPORT II COR, Daryl Martyris (dmartyris@state.gov). From a technical management perspective, the Evaluation Team will work closely with BLT AOR R. Paul McKee (rmckee@state.gov) and Alternate AOR Mohammad Shiwani (mshiwani@state.gov). In order to maintain objectivity, OPPD's Monitoring and Evaluation Unit will make all final decisions about the evaluation.

\section{FINAL REPORT FORMAT}

The evaluation final report should be about 25 pages in length, not including annexes. It should be written in English, using Times New Roman 12 point font, 1.15 line spacing, and be consistent with USAID branding policy. The report should be structured as follows:

1. Title Page

2. Table of Contents

3. List of any acronyms, tables and/or figures

4. Acknowledgements or Preface (optional)

5. Executive Summary (3-5 pages)

6. Introduction

a. Description of the project evaluated, including goal and expected results

b. Brief statement on purpose of the evaluation, plus a list of the evaluation questions

c. Description of the methods used in the evaluation (such as desk/document review, interviews, site visits, surveys, etc.), the rationale and location for field visits (if any), and a description of the numbers and types of respondents

d. Limitations to the evaluation, with particular attention to the limitations associated with the evaluation methodology (selection bias, recall bias, unobservable differences between comparator groups, etc.)

7. Findings

a. Describe findings, focusing on each of the evaluation questions and providing gender disaggregation where appropriate

b. Evaluation findings should be presented as analyzed facts, evidence, and data and not solely based on anecdotes, hearsay, or the compilation of people's opinions 
8. Conclusions

a. Conclusions are value statements drawn from the data gathered during the evaluation process

9. Recommendations

a. Recommendations should be actionable, practical and specific statements for existing programming and for the design and performance of future programming

b. Each recommendation should be supported by a specific set of findings

c. Include recommended future objectives and types of activities based on lessons learned

10. Annexes

a. Evaluation Scope of Work

b. Methodology description (include any pertinent details not captured in the report)

c. Copies of all survey instruments and questionnaires

d. List of critical and key documents reviewed

e. Schedule of meetings and sources of information (If confidentiality is a concern, the team should discuss and agree upon an approach with USAID)

f. Notes from key interviews, focus group discussions, and other meetings

g. Documentation of any changes to the SOW or evaluation process

h. Statement of differences (if applicable)

\section{OVERALL REPORTING GUIDELINES}

This section should provide overall guidance on the final report quality and style. The evaluation report should represent a thoughtful, well-researched, and well-organized effort to objectively evaluate the validity of the project's hypothesis and the effectiveness of the project. Evaluation reports shall address all evaluation questions included in the SOW and be written in highly professional English, free of grammatical and typographical error, and with professional formatting.

Any modifications to the statement of work, whether in technical requirements, evaluation questions, Evaluation Team composition, methodology, or timeline need to be agreed upon in writing by the SUPPORT II COR. 


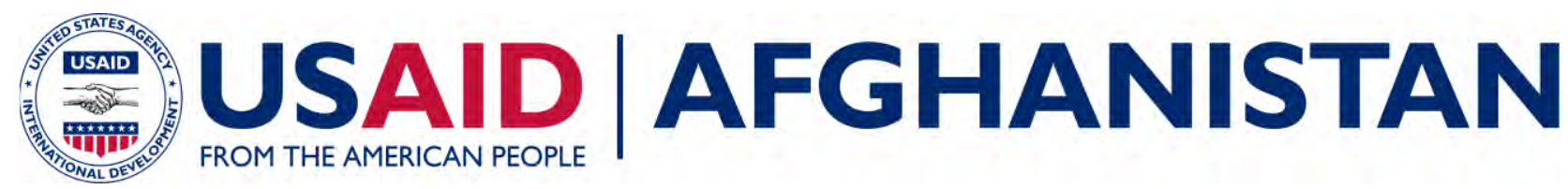

\section{WORKPLAN: FINAL PERFORMANCE EVALUATION AND SUSTAINABILITY ASSESSMENT \\ OF}

THE BUILDING LIVELIHOODS AND TRADE (BLT)

PROGRAM

OF

THE TURQUOISE MOUNTAIN TRUST

Submitted on:

June 2, 2015, revised June 7

Evaluation Team: Michael Lightfoot

Aimee Rose

Burhahuddin Kamal

Manizha Wafeq

Ronald Santos 


\section{Table of Contents}

1. Purpose of the performance evaluation and sustainability assessment............................. 47

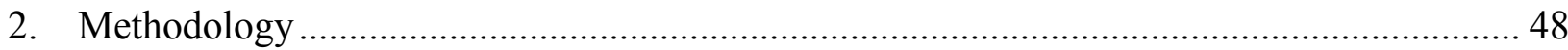

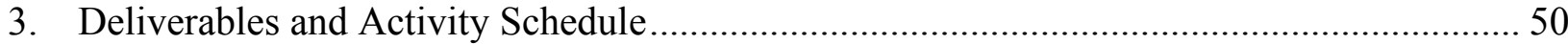

Annex I: Key Evaluation Questions and indictive examples of detailed enquiry questions and

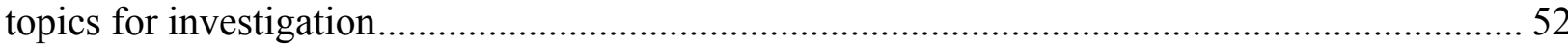




\section{PURPOSE OF THE PERFORMANCE EVALUATION AND SUSTAINABILITY ASSESSMENT}

Turquoise Mountain Trust (TMT), a British-registered non-profit, was founded in 2006 with the vision of restoring the historically and architecturally significant community of Murad Khane in central Kabul. TMT assists the community to access health care andprimary education, and with revitalizing Afghan arts. The Trust has established a training establishment, the Turquoise Mountain Institute (TMI) for Afghan Arts and Architecture, to train young people in the areas of woodwork, ceramics, calligraphy and miniature painting, and jewelry and gem-cutting.

USAID has been supporting TMT since 2008, and in 2010 the program was renamed Building Livelihoods and Trade (BLT). TMT is the contracted authority for implementation through providing ongoing education and training, expanding economic opportunities, and strengthening livelihoods of students and artisans in the handicraft sector of Afghanistan. The program aims to:

- Build economic and trade opportunities for Afghans through the urban regeneration of the Murad Khane area of Old Kabul City

- Provide traditional craft education through TMI; and

- Develop the market for Afghan crafts domestically and abroad through businessdevelopment activities. TMT has been working to realize these BLT aims through

- Reviving and restoring the threatened artistic heritage of Afghanistan;

- Supporting high-quality Technical Vocational Education and Training (TVET)

- Providing livelihood opportunities for TMI students and graduates in the handicrafts sector.

The Total Estimated Cost (TEC) of funding the BLT through TMT since 2008 amounts to $\$ 10,637,111$. Three of the elements - urban regeneration, community development, and business development - were completed in July 2011, leaving only the fourth elementeducation-for continued support to the end of the program in November 2015. The education element is centered on the training provided by TMI.

As the BLT program is in its seventh and final year, it is important to investigate the successes and challenges of the program. The purpose of the BLT final performance evaluation, therefore, is to assess (1) the extent to which economic and trade opportunities for Afghans have been built through the program's initiatives for the economic, social, and cultural regeneration of Murad Khane, (2) the quality of the traditional craft education the program has provided through TMI, and (3) the effectiveness of the program's efforts to market Afghan crafts domestically and abroad through business-development activities. The sustainability assessment has three objectives: (1) Estimate both resource and cost containment that will be required in order for TMI to achieve its strategic institutional goals, (2) Examine revenue streams that can contribute to the long-term financial sustainability of the institution, and (3) Assess the long-term viability of the business.

The evaluation will yield a report that analyzes the extent to which the USAID resources have been deployed to maximum effect in each of the areas where TMT is operating. The sustainability assessment will clearly and concisely outline relevant findings about current 
resource requirements and their utilization. It will review the organizational and program performance, and will articulate conclusions relative to financial independence.

The report will conclude with recommendations for realistic objectives and activities to achieve the goals of a financially sound and stable TMT capable of playing a significant role in Afghanistan's vocational education system, which is preparing for the workforce of tomorrow.

\section{METHODOLOGY}

This assessment will be anchored with a desk review of TMT reports, records, and financial forecasts and statements; strategic planning documents; data from surveys; and interviews with key stakeholders and beneficiaries. The methodology is aligned with USAID's Project Design Sustainability Analysis Tool.

The following quantitative and qualitative data will be collected for analysis:

\begin{tabular}{|c|c|c|c|}
\hline & Method & Data & Sources \\
\hline a. & $\begin{array}{l}\text { Financial Review } \\
\text { and analysis } \\
\text { comparing budget } \\
\text { with actuals 2008- } \\
2015\end{array}$ & $\begin{array}{l}\text { - Financial records including } \\
\text { P\&L accounts and Balance } \\
\text { Sheet } \\
\text { - Salary/payroll data } \\
\text { - Purchasing policy and data } \\
\text { - Breakdown of income } \\
\text { sources } \\
\text { - Sales figures } \\
\text { - Cost information from } \\
\text { comparable institutions }\end{array}$ & $\begin{array}{l}\text { - TMT financial records } \\
\text { - Quarterly and annual } \\
\text { reports to the TMT } \\
\text { Board } \\
\text { - Other institution's cost } \\
\text { information }\end{array}$ \\
\hline b. & Document Review & $\begin{array}{l}\text { - Planning documents } \\
\text { - Financial records } \\
\text { - Proposals and plans } \\
\text { - Sales literature } \\
\text { - Curriculum docs } \\
\text { - Assessment and award } \\
\text { records } \\
\text { - Student recruitment, } \\
\text { retention and progression } \\
\text { data }\end{array}$ & $\begin{array}{l}\text { - } \text { Reports to USAID } \\
\text { - } \text { Quarterly and annual } \\
\text { reports to the TMT Board } \\
\text { - } \text { Reports from } \\
\text { qualifications awarding } \\
\text { body } \\
\text { - } \text { Student records }\end{array}$ \\
\hline c. & Literature Review & $\begin{array}{l}\text { - Case studies from other } \\
\text { social enterprise initiatives in } \\
\text { LDCs } \\
\text { - Evaluation and final reports } \\
\text { of related projects } \\
\text { - Quantitative and quantitative } \\
\text { research of relevance }\end{array}$ & $\begin{array}{l}\text { - Government } \\
\text { - Donors, } \\
\text { - NGOs } \\
\text { - Journals } \\
\text { - Research bodies }\end{array}$ \\
\hline d. & $\begin{array}{l}\text { In-depth interviews } \\
\text { with key } \\
\text { informants }\end{array}$ & - Notes and transcripts & $\begin{array}{l}\text { - TMT staff, } \\
\text { - Community leaders, } \\
\text { - Board members, }\end{array}$ \\
\hline
\end{tabular}




\begin{tabular}{|l|l|l|l|}
\hline & & & $\begin{array}{l}\text { - Employers } \\
\text { - Other stakeholders }\end{array}$ \\
\hline e. & $\begin{array}{l}\text { A survey of the } \\
\text { Murad Khane } \\
\text { community }\end{array}$ & $\begin{array}{l}\text { - Survey data } \\
\text { - Surveyor debriefing notes }\end{array}$ & $\begin{array}{l}\text { Representatives of } \\
\text { randomly selected Murad } \\
\text { Khane households }\end{array}$ \\
\hline f. & $\begin{array}{l}\text { Focus group } \\
\text { discussions with } \\
\text { current and past } \\
\text { students }\end{array}$ & - Notes and transcripts & $\begin{array}{l}\text { Current and past students; } \\
\text { selected at random where } \\
\text { possible }\end{array}$ \\
\hline g. & $\begin{array}{l}\text { A survey of current } \\
\text { students and a } \\
\text { survey of past } \\
\text { students }\end{array}$ & $\begin{array}{l}\text { - Survey data } \\
\text { - Surveyor debriefing notes }\end{array}$ & $\begin{array}{l}\text { Randomly selected current } \\
\text { and past students }\end{array}$ \\
\hline h. & $\begin{array}{l}\text { Site visits and } \\
\text { classroom } \\
\text { observations }\end{array}$ & $\begin{array}{l}\text { - Observation notes } \\
\text { checklist }\end{array}$ & - Photographs
\end{tabular}

The methods and data sources correspond to the evaluation questions in the following way:

\begin{tabular}{|c|c|c|c|c|c|c|c|c|c|}
\hline \multirow[t]{2}{*}{ \# } & \multirow[t]{2}{*}{ EVALUATION QUESTIONS } & \multicolumn{8}{|c|}{ METHODS } \\
\hline & & $\mathrm{a}$ & $\mathrm{b}$ & c & $\mathrm{d}$ & $\mathrm{e}$ & $\mathrm{f}$ & $\mathrm{g}$ & $\mathrm{h}$ \\
\hline 1 & $\begin{array}{l}\text { Livelihoods: To what extent has the program } \\
\text { activities/initiatives contributed to increasing the } \\
\text { economic opportunities for Afghan artisans and } \\
\text { businesses? }\end{array}$ & & $\mathrm{X}$ & $\mathrm{X}$ & $\mathrm{X}$ & $\mathrm{X}$ & $\mathrm{X}$ & $\mathrm{X}$ & \\
\hline 2 & $\begin{array}{l}\text { Trade: How effective has the program been in } \\
\text { improving the ability of beneficiaries (students, } \\
\text { artisans, and businesses) to market crafts } \\
\text { domestically and abroad? }\end{array}$ & & $\mathrm{X}$ & $\mathrm{X}$ & $\mathrm{X}$ & & $\mathrm{X}$ & $\mathrm{X}$ & \\
\hline 3 & $\begin{array}{l}\text { Quality: To what extent has the program increased } \\
\text { the quality of products produced by project } \\
\text { beneficiaries (students, artisans, and businesses)? }\end{array}$ & & $\mathrm{X}$ & $\mathrm{X}$ & $\mathrm{X}$ & & $\mathrm{X}$ & $\mathrm{X}$ & $\mathrm{X}$ \\
\hline 4 & $\begin{array}{l}\text { Rehabilitation: How satisfied is the target } \\
\text { community with the neighborhood rehabilitation } \\
\text { efforts initiated by TMT/TMI and are the results } \\
\text { sustainable? }\end{array}$ & & $\mathrm{X}$ & $\mathrm{X}$ & $\mathrm{X}$ & $\mathrm{X}$ & & & \\
\hline 5 & $\begin{array}{l}\text { Cost: To what extent was TMI's three-year TVET } \\
\text { program a cost-effective means of educating male } \\
\text { and female handicraft professionals that are } \\
\text { demanded by the Afghan market? }\end{array}$ & $\mathrm{X}$ & $\mathrm{X}$ & & & & $\mathrm{X}$ & $\mathrm{X}$ & $\mathrm{X}$ \\
\hline 6 & $\begin{array}{l}\text { Gender: To what extent has BLT benefitted both } \\
\text { male and female artisans and business people? }\end{array}$ & & $\mathrm{X}$ & & $\mathrm{X}$ & & $\mathrm{X}$ & $\mathrm{X}$ & $\mathrm{X}$ \\
\hline & TAINABILITY & & & & & & & & \\
\hline 1 & $\begin{array}{l}\text { As the BLT program comes to an end, to what } \\
\text { extent are TMI's operational costs covered by } \\
\text { existing or planned future revenue streams from } \\
\text { sources other than USAID or other donors? Please }\end{array}$ & $\mathrm{X}$ & $\mathrm{X}$ & & $\mathrm{X}$ & & & & \\
\hline
\end{tabular}




\begin{tabular}{|l|l|l|l|l|l|l|l|l|}
\hline & $\begin{array}{l}\text { examine reliability and stability of any market- } \\
\text { based revenue streams. }\end{array}$ & $\begin{array}{l}\text { lan the current structure of TM-including TMT, } \\
\text { TM create a fully sustainable and profitable public- } \\
\text { private partnership and business venture that is } \\
\text { capable of meeting the objectives of (a) creating a } \\
\text { strong Afghan "brand", (b) establishing wide } \\
\text { market presence, and (c) generating robust } \\
\text { domestic and overseas sales? }\end{array}$ & $\mathrm{X}$ & $\mathrm{X}$ & & & \\
\hline 3 & $\begin{array}{l}\text { To what extent are the Afghan handicraft } \\
\text { enterprises with which TMT and TMI collaborate } \\
\text { sustainable, independent and business-savvy } \\
\text { organizations that are capable of providing quality } \\
\text { jobs to male and female graduates of TMI and } \\
\text { ensuring adequate revenue streams? }\end{array}$ & $\mathrm{X}$ & $\mathrm{X}$ & & & \\
\hline
\end{tabular}

\section{TEAM MEMBERS}

Michael Lightfoot (TL), TVET and QA Specialist

Email:-michaeldlightfoot@gmail.com

Tel: +93 (0) 729001684

Aimee Rose, Checchi Consulting M\&E Practice Manager

Email: arose@checchiconsulting.com

Tel: +93 (0) 729001671

Burhanuddin Kamal, M\&E specialist

Email: kburhan@,checchiconsulting.com

Tel: +93 (0) 729001666

Manizha Wafeq

Email: mwafeq@,checchiconsulting.com

Tel: +93(0) 729001696

Ronald Santos, Technical Director and data analyst

Email: rsantos@checchiconsulting.com

Tel: +93 (0) 729001697

VI. III. DELIVERABLES AND ACTIVITY SCHEDULE

\begin{tabular}{|l|l|}
\hline Deliverables & Date Due \\
\hline In-briefing / SOW Presentation & Mon, 1 June \\
\hline Draft Work Plan to USAID & Tue, 2 June \\
\hline Final/USAID-approved SOW/Workplan & Thu, 4 June \\
\hline Interim briefing on evaluation and sustainability analysis & Sun, 14 June \\
\hline Presentation of findings & Thu, 25 June \\
\hline
\end{tabular}




\begin{tabular}{|l|l|}
\hline Draft of report submitted & Mon, 29 June \\
\hline Comments back from USAID & Sun, 5 July \\
\hline Final revised report & Sun, 11 July \\
\hline
\end{tabular}

\section{Timeline}

\begin{tabular}{|l|l|}
\hline \multicolumn{1}{|c|}{ Weeks } & \\
\hline $\begin{array}{l}\text { W1 } \\
\text { June 3 } 3\end{array}$ & $\begin{array}{l}\text { Sat, 30 May: TL arrival and initial team meeting } \\
\text { Mon, 1 June : In-briefing at USAID } \\
\text { Team meeting at TMT }\end{array}$ \\
Wed, 3 June \& \\
Thu, 4 June: Team deploy to TMT for initial interviews \\
\hline Wune 6-10 & $\begin{array}{l}\text { Meeting with Board members } \\
\text { Tnterviews with teachers, community members, clients / business partners of } \\
\text { TMT } \\
\text { Survey of students - telephone and face-to-face }\end{array}$ \\
\hline June 20-24 11 & $\begin{array}{l}\text { Preparation of Key findings - presentation of Key findings and conclude } \\
\text { draft report and internal distribution for team comments }\end{array}$ \\
\hline $\begin{array}{l}\text { W3 } \\
\text { June 13-17 }\end{array}$ & $\begin{array}{l}\text { Continue interviews with teachers, community members, clients / business } \\
\text { partners of TMT } \\
\text { Focus group meetings with current and past students } \\
\text { Survey of community }\end{array}$ \\
\hline
\end{tabular}




\section{ANNEX: KEY EVALUATION QUESTIONS AND INDICTIVE EXAMPLES OF DETAILED ENQUIRY QUESTIONS AND TOPICS FOR INVESTIGATION}

The investigation of BLT will be comprised of two distinct components: (1) a final evaluation of seven years of USAID program management, and (2) a sustainability assessment of TMI and the Afghan handicraft enterprises with which it works.

Final Evaluation Questions:

(1) Livelihoods: To what extent has the program activities/initiatives contributed to increasing the economic opportunities for Afghan artisans and businesses?

(2) Trade: How effective has the program been in improving the ability of beneficiaries (students, artisans, and businesses) to market crafts domestically and abroad?

(3) Quality: To what extent has the program increased the quality of products produced by project beneficiaries (students, artisans, and businesses)?

(4) Rehabilitation: How satisfied is the target community with the neighborhood rehabilitation efforts initiated by TMT/TMI and are the results sustainable?

(5) Cost: To what extent was TMI's three-year TVET program a cost-effective means of educating male and female handicraft professionals that are demanded by the Afghan market?

(6) Gender: To what extent has BLT benefitted both male and female artisans and business people?

Sustainability Assessment Questions:

(7) As the BLT program comes to an end, to what extent are TMI's operational costs covered by existing or planned future revenue streams from sources other than USAID or other donors? Please examine reliability and stability of any marketbased revenue streams.

(8) Can the current structure of TM-including TMT, TMI, and all partner organizations - be mobilized to create a fully sustainable and profitable publicprivate partnership and business venture that is capable of meeting the objectives of (a) creating a strong Afghan "brand", (b) establishing wide market presence, and (c) generating robust domestic and overseas sales?

(9) To what extent are the Afghan handicraft enterprises with which TMT and TMI collaborate sustainable, independent and business-savvy organizations that are capable of providing quality jobs to male and female graduates of TMI and ensuring adequate revenue streams?

Indicative questions and topics for investigation at TMT under relevant headings: 


\section{Students /graduates - recruitment, retention, and progression}

(1) Who are the students, demographically (male/female, socio/economic status, etc.)?

(2) Where from (from Kabul vs provinces)?

(3) Prior experience/qualifications - what are the entrance requirements?

(4) Use of waiting list for potential students?

(5) Methods of recruitment - advertising/website/other?

(6) Why have trainees chosen TMI over other TVET providers?

(7) Retention/drop-out rate - is there any pattern to the drop-outs (vocation sector or students' backgrounds)?

(8) Progression - employment - where?, what level?; or HE numbers and \% for each of the 4 disciplines (Jewelry, calligraphy, carpentry, ceramics)

(9) Number of applicants to places awarded (in each of the 4 above)?

\section{Human Resources}

Does the staffing match students' and employers' needs?

Analyze:

- Details of staff - numbers of teaching vs. administration

- Background of staff - qualifications and experience

- Proportion of full time to part time staff

- Staff recruitment and retention

- Salaries compared with median Afghan and similar private training providers

- Appraisal policies

- Opportunities for professional development

\section{Leadership management and strategic planning}

(1) How is the TMT organized and run - what is the management and reporting structure?

(2) Are TMT's governance and management structures sufficient to ensure transparency and accountability, is there adequate community and private sector representation?

(3) Does the TMI fit within the MOE's broader strategy and vision for technical and vocational training?

(4) Is there distributed leadership and management in the different parts of the organization - e.g., commercial, community, training?

Consider:

- Organization chart showing management and distribution of responsibilities

- Line management responsibilities and duties

- Stakeholder involvement in strategic planning

- Constitution and role of governors

- Extent of planning for sustainability

\section{Finances}

(1) What are all of the income sources? Which other donor agencies are involved besides USAID, and to what extent?; What became of the Prince's Trust from the UK?

(2) What are the annual budgeting procedures? Is there, for example, zero base budgeting department by department? 
(3) How is the budget distributed and the policies for allocation and accountability (e.g. \% of budget on staff vs. resources)?

(4) What is the policy on repairs/renewals and maintenance ?

(5) Are capital items (e.g., computers) depreciated?

(6) What is the staff student ratio in the TMI and in the local primary school under the wing of the TMT operation?

(7) Is there any notion of calculating a unit cost per student based upon each of the vocational programs?

(8) How stable is the cost base been matched with a growth in student numbers?

(9) What is the financial model/diversity of income streams/unit cost base in comparable TVET institutions internationally (preference to regional models)?

\section{Facilities}

(1) Accommodation - quality and mix of classroom and workshop facilities

(2) Resources for learning - books, equipment, computers

(3) IT infrastructure - network utility/maintenance

(4) Residential accommodation - quality, health, and safety

\section{Curriculum}

(1) Nature of taught courses - where has the curriculum come from? Is it leveled with any form of national or international qualifications or national occupational skill standards?

(2) Duration of courses and balance of theory and practical - do the courses contain a sensible balance of theory and practical work? Are there work experience or opportunities for apprenticeships?

(3) To what extent are the courses relevant, market-sensitive and demand driven?

(4) What is the quality of teaching and learning (e.g. methods, assessments, record keeping, student progression year on year)?

(5) What is the quality of support/guidance and counseling including careers guidance?

\section{Stakeholder Relations}

(1) Stakeholder involvement in:

a. Curriculum (choice, design, review, and renewal)

b. Finance for fees, bursaries, and awards

c.Providing work experience/apprenticeships

d. Providing job placement

e.Community projects

(2) Are all categories of stakeholder represented?

(3) Do employers provide careers counseling?

(4) What is the involvement of employers in strategic planning? 


\section{ANNEX III: BIBLIOGRAPHY OF DOCUMENTS REVIEWED}

Accelerating Quality Jewelry Production in Kabul, (TFBSO project). McColm and Company, 2014

http://www.mccolmandco.com/uploads/9/3/2/8/9328321/mcco_casestudy kabuljewelryprodu ction.pdf (accessed 21 June 2015).

Naimi, Shaila. Independent Survey Report on the Local (non-TM) Jewelry Businesses, Business Development Status, Opportunities and Challenges in Chicken Street, Kabul; and the Status of General Compliance to International Production Standards, - February 2015.

Turquoise Mountain Trust, Community Survey 2013 (in annual report).

Turquoise Mountain Institute: Strategic Planning and Sustainability, TMT (2015).

Turquoise Mountain Trading Limited: position paper Q2 2015, TMT.

Turquoise Mountain, Workplan 2015.

Turquoise Mountain, Re-Branding Afghanistan, Fivbe-Year Program 2015-2020.

TMI - Curriculum documents and timetables

TMT financial statements

UNESCO - National TVET Strategy for Afghanistan 2013-2018, Kabul, 2013

USAID - Annual, monthly and quarterly reports from TMT

World Bank - NSDP - http://www.worldbank.org/projects/P102573/afghanistan-skillsdevelopment-project?lang=en - accessed 23 March 2014 


\section{ANNEX IV: METHODOLOGY DESCRIPTION}

This project was commissioned by USAID at very short notice, so necessarily, the research design had to be formulated very quickly. The research sits upon twin foundations, each of which complements the other. The quantitative elements have been satisfied through the accounts and audit statements that were provided to the team. Through these, the team was able to interrogate the logic and to judge how realistic the future plans are, in relation to the track record and the prevailing market and social conditions in Afghanistan.

TM is an organization that has, from its inception, projected a very strong public profile, and to test the veracity of the many claims of its leadership, the team was keen to interview as many stakeholders as possible to ascertain the authenticity of the claims. The team interviewed by telephone as many of the 187 graduates as was possible in the time available (the data-collectors were able to reach 108 of the graduates); the findings of these independent interviews conducted with the research team, were triangulated with the findings of the TM's own research. This qualitative methodology was augmented through holding focus groups for male and female graduates.

The team interviewed more than 20 business that have some association with TM, and six that do not TM, but operate independently and found their own routes to market both locally and internationally. Since many of the traders and customers are operating from the UK and the US, Skype interviews were held with individuals and organizations that have been or are associated either with TM or with the trading of Afghan goods more generally. Since the beneficiaries of the social interventions are so few in number and so close to the Murad Khane headquarters in the restored serai, it was possible to interview all of the families in the district immediately abutting the TM compound. These 86 families reside in just 56 dwellings. Equally, the impact on primary health care was assessed through checking the records and interviewing community members who have benefited from the operation of the Ferozkoh Clinic.

This mixed-method approach is entirely appropriate for this sort of evaluation and sustainability assessment, since the history of financial accounts must be contextualized into the present and then a planned future. To provide richness and authenticity to the assessment of the plans, it is necessary to widely consult all current and potential stakeholders.

In vocational education and training, the quality of the education outcomes is most accurately judged by those who may be in a position to employ the graduates - and it was for this reason that a great number of employers was consulted. Finally, through holding focus groups, it is possible to gain a view of student satisfaction and how their careers have progressed upon leaving TMI. There are known limitations to focus groups, and the handling of these consultative exercise by skilled and discerning researchers is the only way to ensure that the event is not hijacked by a self-opinionated minority, and that all present are able to express their views.

The major limitation to this project has been the very rapid deployment and the limited time to undertake a fully detailed and comprehensive survey of the market place and the competitors and potential partners for TM as it moves forward. A few independent crafts people were identified and interviewed and one major NGO-related craft trading organization was consulted, but the team felt that this aspect of the sustainability assessment was only touched upon and more time would be necessary to provide a fully comprehensive picture in this respect. 


\section{ANNEX V: DATA COLLECTION INSTRUMENTS}

\section{Student Survey}

Student Id No:

Today's Date:

a) Date of enrolment at TMI

b) Specialism:

c) Age:

d) Gender: $M / F$

c) Home Afghan province:

1. How many brothers and sisters do you have?

2. What is your father's occupation?

3. Does your mother work?

a) Yes

b) No

4. What is your father's highest level of education?
a) Primary
b) Secondary
d) Diploma
e) Bachelors
f) Masters
g) No formal education

5. What is your mother's highest level of education?

As above a), b), c), d), e), f), g).

6. How would you describe the predominant style of teaching at TMI?
a) Interactive
(instructor involves the students in the lessons)
b) Lecture style (instructor does all or most of the talking)
c) Practical - hands-on sessions with equipment

7. How would you rate the resources at TMI?

(workshops, computers, books, materials and equipment)
a) Poor
b) Average
c) Above average

8. How often do you contribute verbally in the class?
a) not at all
b) once a week 

c) every lesson

9. If a student is failing or not doing well in class what does the instructor do to assist them to improve?
a) Nothing
b) Verbal encouragement
c) Extra work to do after class alone
d) Other, please specify

10. How do you feel you are treated by instructors at TMI?
a) not fairly
b) fairly
c) very fairly

11. How helpful do you think TMI is in preparing you for working immediately and/or your long term career ambitions?
a) not helpful
b) a little helpful
c) helpful
d) very helpful

12. Have you received any advice on job-seeking or further training from staff at the TMI?
a) Yes
b) No

13. How many days, during the last month were you absent from TMI?
a) 2 days
b) 4 days
c) 8 days
d) 10 days or more
e) Never

14. Do you enjoy attending the TMI?
a) Yes
b) No

15. How many of your instructors would describe as encouraging?
a) None of them
b) A few of them
c) Some of them
d) Most of them
e) All of them

16. Is there a way in which students can express concerns or make suggestions to the management at the TMI?

a) No 
b) Yes, please describe

17. How often do you use reference books?
a) Not at all
b) Once a year
c) More than twice a semester

18. What do you want to do when you complete the training?
a) University, or continuing education (please insert school or type
b) A job in : Ceramics / Jewelry / Carpentry / Calligraphy / Other
c) Instructor / teacher
d) Other (please list

19. Do you think TMI provides the same quality of education for male and female students?
a) Yes
b) No (If no, why do you say this?

20. Overall how would you rate the TMI?
a) Terrible
b) Average
c) Good
d) Excellent

\section{Student Focus group questions}

Why did you come to TMI? How do you know about TMI?

What steps have you taken to get registration to TMI?

How easy or hard did you find the process?

If you hadn't come to TMI what would you have done? (ie. what did you friends do ?)

How is your work assessed? - ie. mid-terms, quizzes, finals at the end of each semester? Do you have any long-term assignments that you need to work on over an extended period and/or research?

How do you know how well you are doing ie. what progress you are making as you move through the course? 
How would you describe the curriculum? Would you say it is:

- More theory than practice

- More practice than theory;

- $50 / 50$

What do you want to do when you leave TMI? (don't give prompts, leave it up to the students to suggest)

How will your time at TMI help you to achieve your ambition?

(If the subject hasn't been covered in the discussion so far) Now that you have spent time at TMI, what do you think about the business prospects for graduates who practice the trades they learned here?

What's the best thing about TMI?

If you could change something about TMI, what would it

For The Interviewer:

\section{Survey of Graduates}

Status of Respondent

a) Graduated

b) Current Student

Student Id No:

Today's Date:

a) Year of study at TMI

b) Specialism:

c) Age:

d) Gender: $M / F$

c) Home Afghan province:

4. How many brothers and sisters do you have?

5. What is your father's occupation?

6. Does your mother work?

a) Yes

b) No 
4. What is your father's highest level of education?
a) Primary
b) Secondary
d) Diploma
e) Bachelors
f) Masters
g) No formal education

5. What is your mother's highest level of education?

As above a), b), c), d), e), f), g).

17. How would you describe the predominant style of teaching when you were studying at TMI?
d) Interactive
(Instructor involves the students in the lessons)
e) Lecture style (Instructor does all or most of the talking)
f) Practical - hands-on sessions with equipment

18. How would you rate the resources at TMI?

(Workshops, computers, books, materials and equipment)
d) Poor
e) Average
f) Above average

19. How often did you contribute verbally in the class?
d) not at all
e) once a week
f) every lesson

20. If a student failed or did not do well in class and how did instructor assist them to improve? Nothing
e) Verbal encouragement
f) Extra work to do after class alone
g) Other, please specify

21. How did you feel you were treated by instructors at TMI?
d) not fairly
e) fairly
f) very fairly

22. How TMI did prepare you for immediate work and/or for your long term career ambitions? not helpful
e) a little helpful
f) helpful
g) very helpful

23. Have you received any advice on job-seeking or further training from staff at the TMI after your graduations?

c) Yes 
d) No

24. How many days your were absent from class in a month while you were studying at TMI?
f) 2 days
g) 4 days
h) 8 days
i) 10 days or more
j) Never

25. Did you enjoy attending the TMI?
c) Yes
d) No

26. How many of your instructors would describe as encouraging?
f) None of them
g) A few of them
h) Some of them
i) Most of them
j) All of them

27. Were there ways in which students could express concerns or made suggestions to the management at the TMI?
c) No
d) Yes, please describe

17. How often did you use reference books?
a) Not at all
b) Once a year
c) More than twice a semester

18. Do you think TMI provides the same quality of education for male and female students?
a) Yes
b) No (If no, why do you say this?

19. If education at TMI had cost you, would you have been able to attend?
a) Afs. 1000
Yes
No
b) Afs. 2000
Yes
No
c) Afs. 3000
Yes No

20. What did you do when you completed the training?

e) University, or continuing education (please insert school or type

f) A business in: Ceramics / Jewelry / Carpentry / Calligraphy / Other

g) A job in: Ceramics / Jewelry / Carpentry / Calligraphy / Other

h) Instructor / teacher

i) Other (please list 
21. Are you currently doing the same thing now?

a) Yes

b) University, or continuing education (please insert school or type

c) A business in: Ceramics / Jewelry / Carpentry / Calligraphy / Other

d) A job in: Ceramics / Jewelry / Carpentry / Calligraphy / Other

e) Instructor / teacher

f) Other (please list ) visited?

22. If you have started your business or you are working in a crafts business where do you sell your products?
a) Afghanistan (where?)
b) Afghanistan and Abroad (where?)
c) Abroad (where?)

23. Overall how would you rate the TMI?
e) Terrible
f) Average
g) Good
h) Excellent

\section{TM Graduates Focus Group Questions}

In which year did you graduate from TM ? ( list the year of graduation for each of the grads in the focus group)

Why did you go to TM ? to learn a trade or just to get a qual ( we have found, for example that about $1 / 3$ of grads do not go into the trade but go onto uni or some other form of study)

Since you left TM what have you been doing (eg. earning a living/further study) ?

Did TM prepare you well for what you are doing now?

When you started a job, or went on for further study, did you feel well prepared for this next step?

What did you feel were you main weaknesses / shortcomings when starting work for the first time, on graduation from TM? 
Have you found the City \& Guilds Certificate to be a valuable qualification when seeking a job or furthering your career?

Please give me an idea about what life is like for a student at TM? for example: - relaxed, pressurised, the work is easy: the work is hard I am excited and always keen to attend each day; It is sometimes quite boring and I wonder what is the point

How was your work assessed at TM? Was it pretty easy to pass

How do you know how well you are doing ie. what progress you are making as you voce through the course?

How will your time at TMI help you to achieve your ambition?

What's the best thing about TMI?

If you could change something about TMI, what would it be?

\section{Murad Khane HH Survey}

\section{Demographics}

\begin{tabular}{|c|c|c|}
\hline 1 & Number of members in the family & \\
\hline 2 & Ethnicity & $\begin{array}{l}\text { | Tajik } \\
\text { | Pashtun } \\
\text { | Qezelbash } \\
\text { | Hazara } \\
\text { | Other }\end{array}$ \\
\hline 3 & When did your family move to Murad Khane? & \begin{tabular}{l|l}
$\ldots$ & Always lived here $\rightarrow$ Q6 \\
$\mid$ & Before TM (2007 or earlier) \\
$\mid$ & After TM (2008 - 2012) \\
$\mid$ & After TM (2013 or more recently)
\end{tabular} \\
\hline 4 & Where did your family move from? & $\begin{array}{l}\text { Other part of Kabul } \\
\text { Outside Kabul }\end{array}$ \\
\hline 5 & Why did your family move to Murad Khane? & \\
\hline
\end{tabular}

\section{Rehabilitation}

\begin{tabular}{|l|l|l|}
\hline $\mathbf{6}$ & $\begin{array}{l}\text { (If family moved recently skip to Q15) Did } \\
\text { Turquoise Mountain do any construction or } \\
\text { rehabilitation work on your house? }\end{array}$ & I_ I Yes \\
\hline $\mathbf{7}$ & How would you describe the quality of & N_ \\
\hline
\end{tabular}




\begin{tabular}{|c|c|c|}
\hline & rehabilitation work (read answer choices)? & 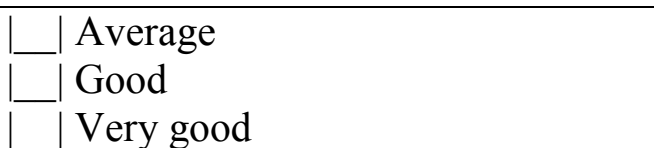 \\
\hline 8 & $\begin{array}{l}\text { Since the first work was done, have you had to } \\
\text { have any repairs done? }\end{array}$ & $\begin{array}{l}\text { Yes } \\
\text { No }\end{array}$ \\
\hline 9 & How many times have repairs been done? & \\
\hline 10 & $\begin{array}{l}\text { Who made the repairs? Was it (read answer } \\
\text { choices) ... .? }\end{array}$ & $\begin{array}{l}\text { I You/your family } \\
\text { | Turquoise Mountain only } \\
\text { | Hired someone } \\
\text { | Both you and Turquoise Mountain }\end{array}$ \\
\hline 11 & $\begin{array}{l}\text { Would you be able to do the repairs yourself if TM } \\
\text { wasn't there? }\end{array}$ & $\begin{array}{ll}\mid \text { Yes } \\
\text { No }\end{array}$ \\
\hline 12 & Why not? & \\
\hline 13 & $\begin{array}{l}\text { Do you think the way Turquoise Mountain did the } \\
\text { rehabilitation was fair for all families? }\end{array}$ & $\begin{array}{l}\text { Yes } \\
\text { No }\end{array}$ \\
\hline 14 & Why not? & \\
\hline \multicolumn{3}{|c|}{ Community Consultations - MALE } \\
\hline 15 & $\begin{array}{l}\text { When TM came to Murad Khane, did they consult } \\
\text { with the male head of your household about the } \\
\text { planned work? }\end{array}$ & $\begin{array}{l}\text { I Yes } \\
\text { I No }\end{array}$ \\
\hline 16 & $\begin{array}{l}\text { How often was the male head of household } \\
\text { consulted? }\end{array}$ & _ times per \\
\hline 17 & $\begin{array}{l}\text { How was the consultation done? (Check all that } \\
\text { apply.) }\end{array}$ & $\begin{array}{l}\mid \text { One-on-one discussion } \\
\text { | Group discussion } \\
\text { | Other }\end{array}$ \\
\hline 18 & $\begin{array}{l}\text { How satisfied were you with the consultation } \\
\text { process with the male head of your household? }\end{array}$ & $\begin{array}{l}\mid \text { Not satisfied } \\
\mid \text { Somewhat satisfied } \\
\mid \text { Satisfied } \rightarrow \mathbf{Q 2 0}\end{array}$ \\
\hline 19 & Why weren't you completely satisfied? & \\
\hline
\end{tabular}

\section{Community Consultations - FEMALE}

\begin{tabular}{|c|c|c|}
\hline 20 & $\begin{array}{l}\text { When TM came to Murad Khane, did they consult } \\
\text { with the female head of your household about the } \\
\text { planned work? }\end{array}$ & $\begin{array}{l}\text { Y Yes } \\
\text { I No }\end{array}$ \\
\hline 21 & $\begin{array}{l}\text { How often was the female head of household } \\
\text { consulted? }\end{array}$ & L_ times per \\
\hline 22 & $\begin{array}{l}\text { How was the consultation done? (Check all that } \\
\text { apply.) }\end{array}$ & $\begin{array}{l}\mid \text { One-on-one discussion } \\
\ldots \text { | Group discussion } \\
\mid \text { | Other }\end{array}$ \\
\hline 23 & $\begin{array}{l}\text { How satisfied were you with the consultation } \\
\text { process with the female head of your household? }\end{array}$ & $\begin{array}{l}\text { Not satisfied } \\
\mid \text { Somewhat satisfied } \\
\text { Satisfied } \rightarrow \mathbf{Q 2 5}\end{array}$ \\
\hline 24 & Why weren't you completely satisfied? & \\
\hline
\end{tabular}




\section{Rehabilitation}

Now I want to ask you about certain types of rehabilitation that was done by Turquoise Mountain.

\begin{tabular}{|c|c|c|c|}
\hline & & $\begin{array}{l}\text { a. How would you describe the } \\
\text { quality of the }\end{array}$ & $\begin{array}{l}\text { b. Do you think the community } \\
\text { would maintain the } \\
\text { without TM? }\end{array}$ \\
\hline 25 & Drainage & $\begin{array}{l}\mid \text { Not good } \\
\ldots \text { | Average } \\
\ldots \text { | Good } \\
\ldots \text { | Very Good }\end{array}$ & $\begin{array}{l}\text { I No } \\
\ldots \mid \text { Unsure } \\
\ldots \\
\text { I Yes }\end{array}$ \\
\hline 26 & $\begin{array}{l}\text { Water } \\
\text { infrastructure }\end{array}$ & $\begin{array}{l}\mid \text { Not good } \\
\text { | Average } \\
\mid \text { Good } \\
\mid \text { Very Good }\end{array}$ & $\begin{array}{ll}\ldots & \text { No } \\
\ldots & \text { Unsure } \\
\ldots & \text { Yes }\end{array}$ \\
\hline 27 & Electricity & $\begin{array}{l}L_{\mid} \text {Not good } \\
\ldots \text { | Average } \\
\ldots \text { Good } \\
\mid \text { Very Good }\end{array}$ & $\begin{array}{ll} & \text { No } \\
\ldots & \text { Unsure } \\
\ldots & \text { Yes }\end{array}$ \\
\hline 28 & $\begin{array}{l}\text { Trash } \\
\text { collection }\end{array}$ & $\begin{array}{l}\ldots \text { Not good } \\
\text { | Average } \\
\text { | Good } \\
\text { | Very Good }\end{array}$ & $\begin{array}{ll} & \text { No } \\
\ldots & \text { Unsure } \\
\text { I Yes }\end{array}$ \\
\hline 29 & $\begin{array}{l}\text { Kocha } \\
\text { rehabilitation }\end{array}$ & $\begin{array}{l}\text { Not good } \\
\text { | Average } \\
\text { | Good } \\
\mid \text { | Very Good }\end{array}$ & $\begin{array}{ll}\ldots & \text { No } \\
\ldots & \text { Unsure } \\
\ldots & \text { Yes }\end{array}$ \\
\hline
\end{tabular}

\section{Livelihoods}

30. Now I want to ask about the occupations of your family members. First, let's list the family members who are 18 years and older and live with you. (List). Are there any other family members who lived here when Turquoise Mountain first arrived? (List them as well).

\begin{tabular}{|c|c|c|c|c|c|c|c|c|c|c|c|c|c|c|c|c|c|c|c|c|c|}
\hline & & & & & & & 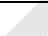 & & $x$ & & & & & & & & & & & & \\
\hline Name & $\begin{array}{l}\mathrm{M} \\
\mathrm{F}\end{array}$ & age & 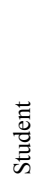 & 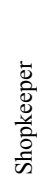 & 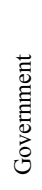 & $\begin{array}{l}\overline{0} \\
\overline{0} \\
\stackrel{0}{\Xi}\end{array}$ & 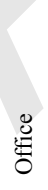 & \begin{tabular}{l}
0 \\
\multirow{2}{0}{} \\
0 \\
0 \\
0 \\
0 \\
0
\end{tabular} & 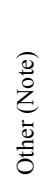 & 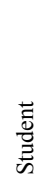 & 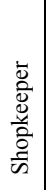 & 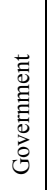 & 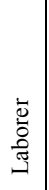 & 遇 & 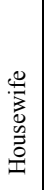 & 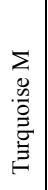 & 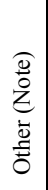 & $\begin{array}{l}\text { Ever } \\
\text { trained } \\
\text { by } \\
\mathrm{TM} \text { ? } \\
\mathrm{Y} / \mathrm{N}\end{array}$ & $\begin{array}{l}\text { If yes, } \\
\text { what? } \\
\text { When? }\end{array}$ & $\begin{array}{l}\text { Ever } \\
\text { empl } \\
\text { by } \\
\text { TM? } \\
\text { Y/N }\end{array}$ & $\begin{array}{l}\text { If yes, what? } \\
\text { When? }\end{array}$ \\
\hline & & & & & & & & & & & & & & & & & & & & & \\
\hline & & & & & & & & & & & & & & & & & & & & & \\
\hline & & & & & & & & & & & & & & & & & & & & & \\
\hline & & & & & & & & & & & & & & & & & & & & & \\
\hline & & & & & & & & & & & & & & & & & & & & & \\
\hline & & & & & & & & & & & & & & & & & & & & & \\
\hline & & & & & & & & & & & & & & & & & & & & & \\
\hline & & & & & & & & & & & & & & & & & & & & & \\
\hline & & & & & & & & & & & & & & & & & & & & & \\
\hline & & & & & & & & & & & & & & & & & & & & & \\
\hline
\end{tabular}

Next we would like to understand how things have changed for your family since 2008 .

When you think about change from then until now? , would you say it has gotten worse, better or there has been no 


\begin{tabular}{|l|l|l|l|l|l|}
\hline & & Worse & $\begin{array}{l}\text { No } \\
\text { Change }\end{array}$ & Better & Why? \\
\hline $\mathbf{3 1}$ & Children's education & & & & \\
\hline $\mathbf{3 2}$ & Access to good health care & & & & \\
\hline $\mathbf{3 3}$ & Ability to find work & & & & \\
\hline $\mathbf{3 4}$ & $\begin{array}{l}\text { Ability to purchase food } \\
\text { and essential items }\end{array}$ & & & & \\
\hline
\end{tabular}

\section{Education}

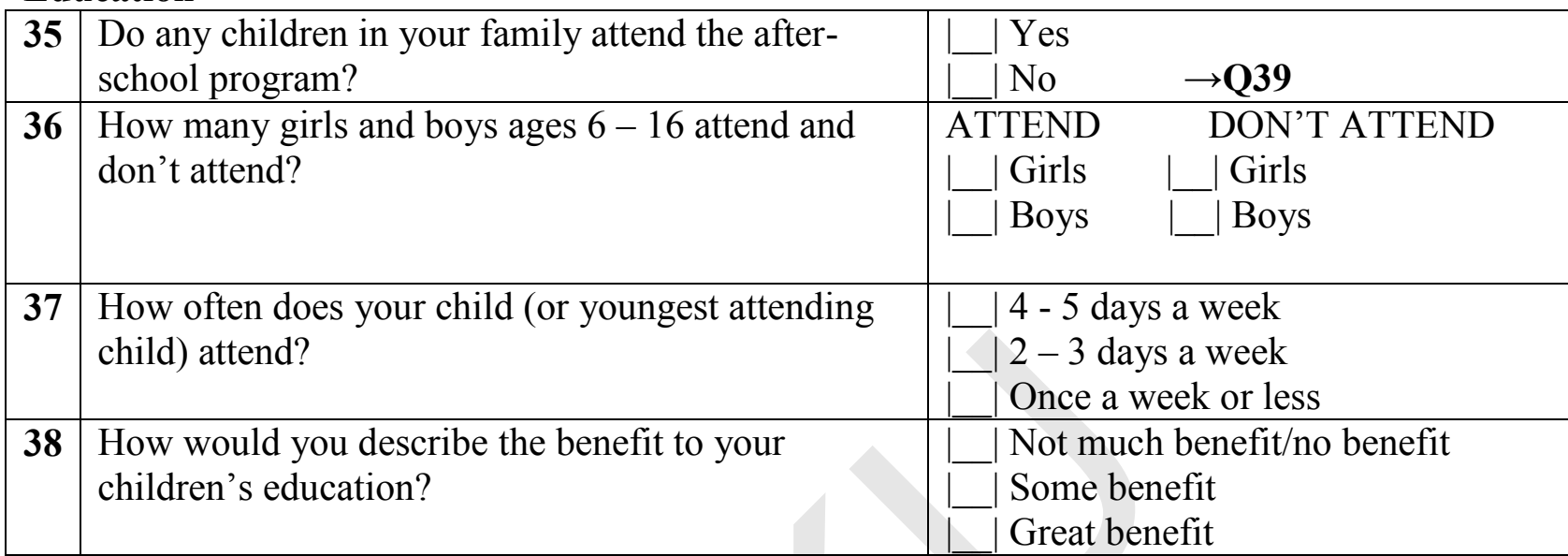

\section{Healthcare}

\begin{tabular}{|c|c|c|}
\hline 39 & $\begin{array}{l}\text { In the last year, have any of your family members } \\
\text { visited the Ferozkoh clinic? }\end{array}$ & $\begin{array}{l}\text { L Yes } \\
\text { INo }\end{array}$ \\
\hline 40 & $\begin{array}{l}\text { How many male and female family members have } \\
\text { gone for medical reasons? }\end{array}$ & 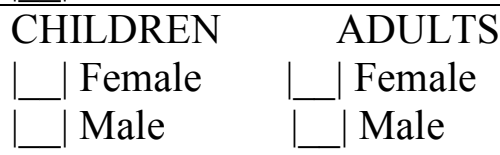 \\
\hline 41 & $\begin{array}{l}\text { What was the reason for your last visit to the } \\
\text { clinic? }\end{array}$ & $\begin{array}{l}\text { I_ Child illness } \\
\ldots \text { | Maternal health } \\
\text { | Adult illness } \\
\text { | Other }\end{array}$ \\
\hline 42 & $\begin{array}{l}\text { How would you describe the quality of the services } \\
\text { at the clinic? }\end{array}$ & $\begin{array}{l}\mid \text { Not good } \\
\mid \text { Average } \\
\mid \text { Good } \\
\mid \text { Very good }\end{array}$ \\
\hline 43 & $\begin{array}{l}\text { Is there anything else you want to tell us about } \\
\text { Turquoise Mountain and its work in Murad Khane? }\end{array}$ & \\
\hline
\end{tabular}




\section{Questions to Companies - jewellery and carpentry - Both those already collaborating with TM and those who do not work with TM}

\section{Graduates / Employees}

Do you have one or more than one TM graduate working for your company?

Describe how you know about TM and the quality of their graduates?

Why did you employ a graduate from TM?

In your opinion do TM graduates have the skills necessary for the job?

Is there anywhere else where you get new employees when you need them?

Are all of your employees full time or are some part time?

How do you cope when you unexpectedly get a big order for jewellery or carpentry?

Would you be prepared to take on a student from TM to work as an apprentice in your workshops for up to three days per week?

Would you be prepared/able to pay them a small salary?

Would you be prepared/able to have an apprentice to work with you for up to one year?

\section{Sales and Marketing}

How do you sell your products? Ie. Do you sell solely through TM ? or direct to market ( what proportion of your output is sold through TM - do you find the size of their brokerage fee $(5 \%)$ to be reasonable?

Have you heard of the Far and Wide Collective?

How do you ensure there is a steady/growing demand for your products?

Are you able to export your products to satisfy demand in overseas markets, or do you mainly sell within Afghanistan? 


\section{Questions to Start-ups}

How long have you been trading?

Why did you start up your own company rather than getting a job with an existing company?

Were you able to raise the capital to start your business quite easily? ( if so where did the capital come from)

Did TM help you with any financial support to start up?

How do you sell your products? through TM, independent of TM, a mixture of the two. Do you work with any other trading / brokerage partner eg. Far and Wide ?

Did the training program at TM provide you with all of the skills and knowledge necessary to start a business?

eg. Writing a business plan?

Marketing strategy?

Sources of finance?

Cash flow management?

Employing people?

Sales in different categories - eg,

direct,

through agents,

with partners,

through TM with their brokerage charges

Can you think of any part of the TM program that could be improved so as to prepare you better for running your own business?

Would you be prepared / able to take on a TM student as an apprentice for up to three days per week, for around one year at a time? Would you be prepared / able to pay them a small salary?

How do you view the future of your business - continuing as an independent trader ? maybe joining and collaborating with other small start-ups in the form of a collective with shared running costs? Selling up to a major company, either local or international? 
Checchi and Company Consulting, Inc.

Afghanistan SUPPORT-II Project

Wazir Akbar Khan

Kabul, Afghanistan 